\title{
NIEMCY WOBEC KRYZYSU MIGRACYJNEGO W UNII EUROPEJSKIEJ W LATACH 2011-2016
}

ABSTRACT Germany and the Migration Crisis in the European Union in the Years 2011-2016 The aim of this research paper is to evaluate the position of Germany, including the federal government and the parliamentary opposition, as regards the migration crisis in the European Union in the years 2011-2016. The first part of the article presents the course of the migration crisis in the presented time period. The second part discusses the evolution of the position of the governing coalition and the parliamentary opposition in Germany towards the first phase of the crisis in the years 2011-2014. The third part has been dedicated to analysing the position of the federal government and the parliamentary opposition towards the second phase of the crisis in the years 2015-2016. The fourth part presents the influence of the German government on the reform of the immigration and asylum policies, as well as the dynamics of the migration crisis in the European Union in the years 2015-2016. The author formulates a research hypothesis that the federal government did not control the migration crisis in the European Union but rather acted impulsively, thereby contributing to its deepening.

Key words: migration crisis, European Union, Lisbon Treaty, European Council, Council of the European Union, European Commission, European Parliament, German government, CDU/CSU, SPD, FDP, Bündnis 90/Die Grünen, Linke, Germany's position on the migration crisis, influence of the German government on the reform of the European Union's immigration and asylum policies

Słowa kluczowe: kryzys migracyjny, Unia Europejska, traktat lizboński, Rada Europejska, Rada Unii Europejskiej, Komisja Europejska, Parlament Europejski, rząd Niemiec, CDU/CSU, SPD, FDP, Sojusz 90/Zieloni, Lewica, stanowisko Niemiec wobec kryzysu migracyjnego, wpływ rządu niemieckiego na reformę polityki imigracyjnej i azylowej Unii Europejskiej 


\section{UWAGI WSTĘPNE}

Celem badawczym pracy jest ocena stanowiska Niemiec, w tym rządu federalnego i opozycji parlamentarnej, wobec kryzysu migracyjnego w Unii Europejskiej w latach 2011-2016 ${ }^{1}$. Pierwsza część pracy przedstawia przebieg kryzysu migracyjnego w prezentowanym okresie. W drugiej części omówiono ewolucję stanowiska koalicji rządowej i opozycji parlamentarnej w Niemczech wobec pierwszej fazy kryzysu w latach 2011-2014. Trzecia część została poświęcona analizie stanowiska rządu federalnego i opozycji parlamentarnej wobec drugiej fazy kryzysu w latach 2015-2016. Natomiast w części czwartej zaprezentowano wpływ rządu niemieckiego na reformę polityki imigracyjnej i azylowej Unii Europejskiej oraz dynamikę kryzysu migracyjnego w Unii Europejskiej w latach 2015-2016. Wbrew dotychczasowym ocenom w literaturze ${ }^{2}$ autor formułuje hipotezę badawczą, że rząd federalny nie zarządzał kryzysem migracyjnym w Unii Europejskiej, ale raczej działał w afekcie i tym samym przyczynił się do pogłębienia kryzysu. Tak było niewątpliwie w kulminacyjnym momencie kryzysu, czyli w okresie od września 2015 r. do marca 2016 r. Mimo to rząd niemiecki starał się wywierać i uzyskał istotny wpływ na reformę polityki imigracyjnej i azylowej Unii Europejskiej w latach 2015-2016.

\section{DYNAMIKA KRYZYSU MIGRACYJNEGO W UNII EUROPEJSKIEJ}

Exodus migrantów do Unii Europejskiej rozpoczął się już w 2011 r. Był on spowodowany m.in. następstwami arabskiej wiosny (2010-2013), konfliktami zbrojnymi w krajach Afryki i Azji oraz powstaniem tzw. Państwa Islamskiego w $2014 \mathrm{r}$. W pierwszej połowie 2011 r. z Afryki Północnej do Włoch przybyło ponad 40 tys. osób. W samych Włoszech doszło do przeludnienia wyspy Lampedusa oraz ogłoszenia przez tamtejsze władze stanu kryzysu humanitarnego. 20 lutego 2011 r. z inicjatywy rządu włoskiego Europejska Agencja Zarządzania Współpracą Operacyjną na Zewnętrznych Granicach Państw Członkowskich Unii Europejskiej (Frontières extérieures - Frontex) rozpoczęła operację „Hermes 2011”, mającą na celu udzielenie wsparcia w nadzorowaniu południowej granicy Unii Europejskiej³. Mimo to od 2011 r. rokrocznie wzrastała liczba migrantów z państw trzecich, ubiegających się o azyl w Unii Europejskiej. O ile w 2011 r. wyniosła ona 309040 osób, o tyle w 2015 r. osiągnęła kulminacyjny pułap 1322825 migrantów,

Artykuł został napisany w ramach grantu Jean Monnet Chair EUCRIS: European Union in Crisis: What is Wrong and How to Fix It?, przyznanego autorowi przez Unię Europejską.

2 F. Trauner, Wie sollen Flüchtlinge in Europa verteilt werden? Der Streit um einen Paradigmenwechsel in der EU-Asylpolitik, „Integration” 2016, Vol. 39, nr 2, s. 93-106; J. Dobrowolska-Polak, Niemieckie przewodnictwo w Unii Europejskiej w procesie zarządzania kryzysem migracyjnym, „Przegląd Zachodni" 2016, nr 3, s. 123-135.

3 J.J. Węc, Pierwsza polska prezydencja w Unii Europejskiej. Uwarunkowania - procesy decyzyjne - osiagnięcia i niepowodzenia, Kraków 2012, s. 199-200, Societas - Księgarnia Akademicka, 44. 
zaś w roku 2016 uległa obniżeniu do poziomu 1259955 osób . To właśnie w latach 2015-2016 napłynęła do Europy największa od czasów II wojny światowej fala masowej migracji ${ }^{5}$. Głównymi szlakami przepływu migrantów były: wschodni szlak śródziemnomorski (z Turcji do Grecji i Bułgarii), centralny szlak śródziemnomorski (z Libii i Egiptu do Włoch) oraz zachodni szlak śródziemnomorski (z Maroka do Hiszpanii). Według danych urzędu Wysokiego Komisarza Narodów Zjednoczonych ds. Uchodźców (United Nations High Commissioner for Refugees - UNHCR) w 2015 r. zdecydowana większość migrantów dostawała się do Unii Europejskiej wschodnim szlakiem śródziemnomorskim (ok. 860 tys. osób), znacznie mniejsza grupa korzystała z centralnego szlaku śródziemnomorskiego (ponad 153 tys. osób), zaś zachodnim szlakiem śródziemnomorskim docierały jedynie nieznaczne grupy (ok. 16 tys. osób) ${ }^{6}$. Jak podaje Eurostat, spośród 1322825 migrantów, którzy złożyli wnioski o azyl w 2015 r., aż ok. 90\% wybrało dziewięć państw członkowskich Unii Europejskiej. Były to: Niemcy (476 510 osób), Węgry (177 135 osób), Szwecja (162 450 osób), Austria (88 160 osób), Włochy (83 540 osób), Francja (76 165 osób), Holandia (44 970 osób), Belgia (44 660 osób) i Wielka Brytania (40 160 osób). W pozostałych państwach członkowskich wnioski takie złożyło 129075 osób, przy czym w Grecji było to 13205 osób (por. tabela 1)7.

Tabela 1. Liczba wniosków o udzielenie azylu złożonych w państwach członkowskich UE w 2015 r.

\begin{tabular}{c|c}
\hline Obszar & Liczba wniosk \\
\hline Unia Europejska (28) & 1322825 \\
\hline Austria & 88160 \\
\hline Belgia & 44660 \\
\hline Bułgaria & 20365 \\
\hline Chorwacja & 210 \\
\hline
\end{tabular}

Eurostat, Asylum and first time asylum applicants by citizenship, age and sex Annual aggregated data (rounded), [dalej: Asylum applicant], s. 1-2, [online] http://appssoeurostat.ec.europa.eu, 26 IV 2017.

5 Szerzej na temat przebiegu kryzysu migracyjnego w Unii Europejskiej por. H. Tendera-Waszczuk, Kryzys migracyjny zagrożeniem dla realizacji projektu zjednoczonej Europy, „Krakowskie Studia Międzynarodowe" 2016, nr 3, s. 9-25; B. Koszel, Unia Europejska, Niemcy i problem uchodźców (2014-2016), „Rocznik Integracji Europejskiej” 2016, nr 10, s. 143-156; A. Potyrała, Pozamilitarne aspekty bezpieczeństwa międzynarodowego - kryzys migracyjny 2015-2016, „Przegląd Strategiczny” 2016, nr 9, s. 295-313.

6 UNHCR, The UN Refugee Agency, Bureau for Europe, II 2017, s. 1-9, [online] https://data2. unhcr.org/en/documents/details/56311, 9 X 2017. Łącznie w 2015 r. agencja Frontex odnotowała aż 1822337 prób nielegalnych wtargnięć przez granice zewnętrzne UE. Dane te nie odzwierciedlają jednak dokładnej liczby migrantów, którzy faktycznie nielegalnie przekroczyli granice zewnętrzne Unii, ponieważ obejmują one także osoby próbujące uczynić to wielokrotnie, por. FRONTEX, Risk Analysis for 2016, Warszawa 2016, s. 16-17.

Eurostat, Asylum applicant, s. 1-2. Według danych Federalnego Urzędu ds. Migracji i Uchodźców (Bundesamt für Migration und Flüchtlinge - BAMF) łączna liczba wniosków azylowych złożonych w RFN w 2015 r. wyniosła 476 649, por. Bundesamt für Migration und Flüchtlinge, Migrationsbericht 2015, 14 XII 2016, s. 1, [online] http://www.bamf.de, 9 X 2017. 


\begin{tabular}{|c|c|}
\hline Obszar & Liczba wniosków \\
\hline Cypr & 2265 \\
\hline Czechy & 1515 \\
\hline Dania & 20935 \\
\hline Estonia & 230 \\
\hline Finlandia & 32345 \\
\hline Francja & 76165 \\
\hline Grecja & 13205 \\
\hline Hiszpania & 14780 \\
\hline Holandia & 44970 \\
\hline Irlandia & 3275 \\
\hline Litwa & 315 \\
\hline Łotwa & 330 \\
\hline Luksemburg & 2505 \\
\hline Malta & 1845 \\
\hline Niemcy & 476510 \\
\hline Polska & 12190 \\
\hline Portugalia & 895 \\
\hline Rumunia & 1260 \\
\hline Słowacja & 330 \\
\hline Słowenia & 275 \\
\hline Szwecja & 162450 \\
\hline Węgry & 177135 \\
\hline Wielka Brytania & 40160 \\
\hline Włochy & 83540 \\
\hline
\end{tabular}

Źródło: Eurostat, Asylum applicant, s. 1-2.

Niebagatelny wpływ na zintensyfikowanie napływu migrantów do Unii Europejskiej miała ogłoszona w nocy z 4 na 5 września 2015 r. błędna, choć być może zrozumiała z powodów humanitarnych, decyzja kanclerz Merkel i kanclerza Austrii Wernera Faymanna o czasowym zawieszeniu przepisów rozporządzenia Dublin III w odniesieniu do ludności syryjskiej, w szczególności zaś wymogu ubiegania się o azyl w pierwszym państwie członkowskim Unii, do którego imigrant się dostanie. W efekcie tej decyzji masowy napływ migrantów do Unii Europejskiej, ale w szczególności do Niemiec, przybrał jeszcze bardziej na sile. Według danych BAMF do końca 2015 r. przybyło do Niemiec 
ok. 890 tys. osób, spośród których 476649 złożyło wnioski o azyl, zaś ok. 413350 przedostało się tam z innych państw członkowskich UE, co doprowadziło do kumulacji dwóch grup migrantów (z państw trzecich i krajów członkowskich UE). Sprawa tych tzw. wtórnych przepływów migrantów pomiędzy państwami członkowskimi stała się później jednym z istotniejszych problemów, będących przedmiotem reformy wspólnego europejskiego systemu azylowego (WESA) $)^{8}$. Spośród wspomnianych wyżej 476649 wnioskodawców w 2015 r. jedynie 140915 osób uzyskało w Niemczech zgodę na azyl, ale i tak była to najwyższa liczba pozytywnych decyzji w całej Unii Europejskiej'.

Jak podaje Eurostat, w 2016 r. napływ imigrantów do Unii Europejskiej był niższy aniżeli w roku poprzednim, ale mimo to osiągnął poziom aż 1259955 osób. Tym razem jednak aż ok. 59\% migrantów wnioski azylowe złożyło w Niemczech, zaś ok. $41 \%$ w pozostałych państwach członkowskich Unii. W liczbach bezwzględnych najwięcej wniosków zarejestrowano w Niemczech (745 545) oraz we Włoszech (122 960). Według danych BAMF łącznie w 2016 r. Niemcy przyjęły 433920 azylantów, co stanowiło, podobnie jak w 2015 r., najwyższą liczbę pozytywnych decyzji w całej Unii Europejskiej ${ }^{10}$.

Łączna liczba wniosków azylowych złożonych w latach 2015-2016 była według danych Eurostatu największa w następujących państwach członkowskich Unii Europejskiej: w Niemczech (1 221 665), we Włoszech (206 500), na Węgrzech (206 565) i w Wielkiej Brytanii $\left(78\right.$ 945) ${ }^{11}$. Oznaczało to, iż na ogólną liczbę 2333710 wniosko-

EASY, czyli system wstępnej rejestracji migrantów ubiegających się o azyl, odnotował do końca 2015 r. aż 1091894 migrantów. Jednak weryfikacja tych danych przez BAMF w ciągu 2016 r. wykazała, że liczba ta była znacznie zawyżona i wyniosła ostatecznie ok. 890 tys. osób. Różnica ta wynikała stąd, że EASY nie wymaga podawania danych osobowych. Dlatego często zdarzały się błędne lub nawet podwójne zapisy w sytemie rejestracji, a nadto niektórzy zarejestrowani w EASY wyjeżdżali następnie do innych państw członkowskich UE. Spośród wspomnianej wyżej grupy liczącej ok. 890 tys. osób 441899 osób złożyło pierwszy, zaś 34750 ponowny wniosek azylowy. BAMF czyni rozróżnienie między pierwszym wnioskiem, ponownym (odwoławczym) i drugim wnioskiem azylowym. Pierwszy wniosek (Erstantrag) azylowy to wniosek, który po raz pierwszy zostaje złożony przez zainteresowaną osobę w BAMF. Jeżeli jednak wycofa ona taki wniosek przed jego rozpatrzeniem lub wniosek ten zostanie w niezaskarżalny sposób odrzucony, to zainteresowany może się odwołać. Ten ponowny wniosek (Folgeantrag) jest jednak rozpatrywany tylko wówczas, gdy pojawią się nowe istotne okoliczności w sytuacji migranta (np. zmiana warunków w kraju pochodzenia lub nowe dowody świadczące o zagrożeniu dla migranta w razie powrotu). Natomiast drugi wniosek (Zweitantrag) azylowy można złożyć wtedy, gdy postępowanie o przyznanie azylu w państwie bezpiecznym w rozumieniu ustawy o azylu (Asylgesetz) z 26 czerwca 1992 r. (państwa UE oraz Norwegia i Szwajcaria) zakończyło się niepowodzeniem, RFN jest krajem uprawnionym do jego rozpatrzenia oraz zaistniały wspomniane wyżej nowe okoliczności w sytuacji migranta. Wtedy taki wniosek traktowany jest przez BAMF jak pierwszy wniosek azylowy. Szerzej na ten temat por. Bundesamt für Migration und Flüchtlinge, Erst-, Folge-, Zweitanträge, 1 VIII 2016, s. 1, [online] http://www.bamf.de, 9 X 2017; Bundesamt für Migration und Flüchtlinge, Migrationsbericht 2015, 14 XII 2016, s. 1, [online] http://www.bamf.de, 9 X 2017.

9 Bundesamt für Migration und Flüchtlinge, Aktuelle Zahlen zu Asyl, Berlin, IV 2017, s. 10, [online] http://www.bamf.de, 9 X 2017.

10 Bundesamt für Migration und Flüchtlinge, Aktuelle Zahlen zu Asyl, s. 10.

11 Do podanych liczb należy jeszcze dodać (zwłaszcza w przypadku Niemiec i Wielkiej Brytanii) tych migrantów, którzy przybyli z innych państw członkowskich Unii. Liczby te na razie mają jedynie charakter szacunkowy. 
dawców (wnioski pierwsze i ponowne) w całej Unii Europejskiej w analizowanym przedziale czasowym aż 52,35\% wniosków przypadło na Republikę Federalną, 8,85\% - na Włochy, 8,85\% - na Węgry, zaś 3,38\% - na Wielką Brytanię. Natomiast w pozostałych 24 państwach członkowskich złożono łącznie $21,68 \%$ wniosków (por. tabela 2$)^{12}$. Jednocześnie, jak podaje BAMF, w latach 2015-2016 Niemcy przyjęły łącznie 574835 azylantów. Ponadto w okresie od stycznia do kwietnia 2017 r. zgodę na azyl w Niemczech uzyskało dalsze 132218 osób (por. tabela 3) ${ }^{13}$.

Tabela 2. Liczba wniosków o udzielenie azylu złożonych

w państwach członkowskich UE w latach 2015-2016

\begin{tabular}{|c|c|c|}
\hline Obszar & 2015 & 2016 \\
\hline Unia Europejska (28) & 1322825 & 1259955 \\
\hline Austria & 88160 & 42255 \\
\hline Belgia & 44660 & 18280 \\
\hline Bułgaria & 20365 & 19420 \\
\hline Chorwacja & 210 & 2225 \\
\hline Cypr & 2265 & 2940 \\
\hline Czechy & 1515 & 1475 \\
\hline Dania & 20935 & 6180 \\
\hline Estonia & 230 & 175 \\
\hline Finlandia & 32345 & 5605 \\
\hline Francja & 76165 & 84270 \\
\hline Grecja & 13205 & 51110 \\
\hline Hiszpania & 14780 & 15755 \\
\hline Holandia & 44970 & 20945 \\
\hline Irlandia & 3275 & 2245 \\
\hline Litwa & 315 & 430 \\
\hline Łotwa & 330 & 350 \\
\hline Luksemburg & 2505 & 2160 \\
\hline Malta & 1845 & 1930 \\
\hline Niemcy & 476510 & 745155 \\
\hline Polska & 12190 & 12305 \\
\hline Portugalia & 895 & 1460 \\
\hline
\end{tabular}

12 Eurostat, Asylum applicant, s. 1-2.

13 Bundesamt für Migration und Flüchtlinge, Aktuelle Zahlen zu Asyl, s. 10. 


\begin{tabular}{|c|c|c|}
\hline Obszar & 2015 & 2016 \\
\hline Rumunia & 1260 & 1880 \\
\hline Słowacja & 330 & 145 \\
\hline Słowenia & 275 & 1310 \\
\hline Szwecja & 162450 & 28790 \\
\hline Węgry & 177135 & 29430 \\
\hline Wielka Brytania & 40160 & 38785 \\
\hline Włochy & 83540 & 122960 \\
\hline
\end{tabular}

Źródło: Eurostat, Asylum applicant, s. 1-2.

Tabela 3. Łączna liczba azylantów przyjętych przez Niemcy w latach 2015-2016 i w pierwszych miesiącach $2017 \mathrm{r}$.

\begin{tabular}{|c|c|c|c|c|}
\hline Rok & Łącznie & $\begin{array}{c}\text { Przyznanie } \\
\text { statusu } \\
\text { uchodźcy na } \\
\text { mocy konwen- } \\
\text { cji genewskiej } \\
\text { z 1951 r. }\end{array}$ & $\begin{array}{c}\text { Przyznanie } \\
\text { ochrony } \\
\text { subsydiarnej }\end{array}$ & $\begin{array}{c}\text { Stwierdzenie } \\
\text { zakazu } \\
\text { deportacji }\end{array}$ \\
\hline 2015 & 140915 & 137136 & 1707 & 2072 \\
\hline 2016 & 433920 & 256136 & 153700 & 24084 \\
\hline $2017^{*}$ & 132218 & 61373 & 51978 & 18867 \\
\hline Eącznie w latach & 707053 & 456645 & 207385 & 45023 \\
\hline $2015-2017^{*}$ & & & & \\
\hline
\end{tabular}

* Dane za 2017 r. obejmują okres od stycznia do kwietnia.

Źródło: Bundesamt für Migration und Flüchtlinge, Aktuelle Zahlen zu Asyl, s. 10.

\section{STANOWISKO RZĄDU FEDERALNEGO I OPOZYCJI PARLAMENTARNEJ W NIEMCZECH WOBEC KRYZYSU MIGRACYJNEGO W UNII EUROPEJSKIEJ}

\section{Pierwsza faza kryzysu (2011-2014)}

Exodus migrantów z Afryki do Włoch w 2011 r., tragiczne losy rozbitków na Morzu Śródziemnym oraz związany z tym kryzys humanitarny na Lampedusie wstrząsnęły nie tylko włoską, lecz także europejską opinią publiczną ${ }^{14}$. Pierwsze reakcje rządu

14 Spośród partii koalicji rządowej najwcześniej stanowisko wobec exodusu migrantów z Afryki do Europy zajęli liberałowie. W uchwalonym 22 kwietnia 2012 r. programie zasadniczym FDP opowiedziała się m.in. za ustanowieniem chroniacego prawa cztowieka prawa azylowego w Unii Europejskiej oraz za tym, aby Niemcy jako państwo niebędące krajem granicznym Unii wniosto solidarny wktad do unijnej 
koalicyjnego CDU/CSU/FDP na te wydarzenia były jednak powściągliwe. Gdy na początku marca 2011 r. włoski minister spraw wewnętrznych Roberto Maroni (Liga Północna) zaapelował do Unii Europejskiej o podjęcie „wszelkich możliwych środków” w celu zapobieżenia kryzysowi humanitarnemu, do którego mogłoby dojść na skutek masowego napływu migrantów do Włoch, spowodowanego wojną domową w Libii ${ }^{15}$, jego niemiecki odpowiednik Thomas de Maizière (CDU) stanowczo sprzeciwił się przyjęciu uchodźców w Niemczech ${ }^{16}$. Wprawdzie w tym samym czasie pełnomocnik rządu federalnego ds. praw człowieka Markus Löning (FDP), który w dniach 8-9 marca 2011 r. odwiedził granicę tunezyjsko-libijską, wzywał do okazania humanitarnych gestów oraz solidarności z Tunezją ${ }^{17}$, ale już 11 kwietnia tegoż roku podczas posiedzenia Rady Unii Europejskiej w Luksemburgu nowy minister spraw wewnętrznych RFN Hans-Peter Friedrich (CSU) ostro skrytykował zapowiedź rządu Włoch w sprawie możliwego udzielenia wiz schengeńskich migrantom z Afryki Północnej oraz zagroził wzmocnieniem kontroli na niemieckich granicach ${ }^{18}$. Było to równoznaczne $\mathrm{z}$ odmową przyjęcia afrykańskich migrantów i wywołało natychmiast ostre reakcje ze strony partii opozycyjnych w Niemczech: Sojuszu 90/Zielonych, Socjaldemokratycznej Partii Niemiec oraz Lewicy ${ }^{19}$.

Także w następnych miesiącach partie te zupełnie inaczej oceniały nasilający się napływ migrantów do Unii Europejskiej. Podczas obrad Federalnej Konferencji Delegatów w dniach 25-27 listopada 2011 r. w Kilonii Sojusz 90/Zieloni przyjął uchwałę, w której krytycznie ocenił wzajemne „targowanie się” (Geschachere) Włoch i Francji o przyjęcie imigrantów z Libii i innych afrykańskich państw upadających, porozumienie włosko-libijskie dotyczące powrotu migrantów, mimo trwającej w Libii wojny domowej, a także odmowę rządu niemieckiego wobec przyjmowania uciekinierów. W ślad za tym Sojusz 90/Zieloni zapowiedział podjęcie działań zmierzających do przyspieszenia prac nad zakończeniem procesu konstytuowania WESA, co skutkowałoby podporządkowaniem tej polityki kontroli parlamentarnej oraz wzmocnieniem demokratyzacji procesu podejmowania decyzji. Jego zdaniem Europa winna przestać odgrywać rolę twierdzy i stać się przystanią dla często znajdujących się w dramatycznym

polityki azylowej, por. 63. Ordentlicher Bundesparteitag der FDP am 22. April 2012 in Karlsruhe, Beschlüsse, Verantwortung für die Freiheit, Karlsruher Freiheitsthesen der FDP für eine offene Bürgergesellschaft, s. 95, [online] http://www.fdp.de, 9 X 2017.

15 Według danych Międzynarodowej Organizacji ds. Migracji (International Organization for Migration - IOM) z powodu wojny domowej w Libii tylko w okresie od 20 lutego do połowy marca $2011 \mathrm{r}$. uciekło do państw ościennych ok. 280 tys. osób, w tym 150 tys. do Tunezji i 120 tys. do Egiptu, por. Nordafrika, Flüchtlinge durch Libyenkrise, Bundeszentrale für Politische Bildung, s. 1, 22 III 2011, [online] https://www.bpb.de, 9 X 2017.

16 Tamże.

17 Tamże, s. 2.

18 Przyczyną takiej deklaracji włoskiego rządu było to, że nie znajdował on wystarczającego wsparcia w Unii Europejskiej w zakresie pomocy dla migrantów. Udzielenie wiz oznaczałoby otwarcie im drogi do wszystkich państw strefy Schengen, w tym także do RFN, por. Flüchtlingsfrage, Italien gegen den Rest Europas, 11 IV 2011, s. 1-2, [online] http://www.zeit.de, 9 X 2017.

19 Nordafrika, Flüchtlinge durch Libyenkrise, s. 2. 
położeniu migrantów ${ }^{20}$. Do reformy polityki azylowej Unii Europejskiej Sojusz 90/ Zieloni nawiązał także w uchwale przyjętej podczas obrad Federalnej Konferencji Delegatów w dniach 16-18 listopada 2012 r. Opowiedział się w niej za rewizją art. 13 rozporządzenia Dublin II, stanowiącego, że państwem uprawnionym do rozpatrzenia wniosku azylowego jest kraj, do którego po raz pierwszy przybędzie imigrant starający się o azy ${ }^{21}$. Zmiana tych przepisów winna polegać na tym, aby wszystkie państwa członkowskie Unii Europejskiej ponosiły w jednakowym stopniu odpowiedzialność za przyjmowanie migrantów. Ponadto Zieloni postulowali złagodzenie restrykcyjnej polityki Frontexu wobec migrantów, zarzucając mu systematyczne naruszanie praw człowieka przez odmowę udzielania zgody na azyl ${ }^{22}$.

Problem coraz większego napływu migrantów z Afryki do Unii Europejskiej centralnym szlakiem śródziemnomorskim był także przedmiotem obrad Zjazdu Federalnego SPD w dniach 4-6 grudnia 2011 r. w Berlinie. Delegaci struktur organizacyjnych niższej instancji złożyli wówczas na forum Zjazdu wnioski programowe, wzywające wprost do gruntownej reformy polityki imigracyjnej Unii Europejskiej oraz niemieckiego prawa azylowego. I tak, przedstawiciele Związku Powiatowego Münster domagali się m.in. odejścia od rygorystycznych zasad funkcjonowania Frontexu oraz zmiany art. 13 rozporządzenia Dublin II w sposób zobowiązujący wszystkie państwa członkowskie do rozpatrywania wniosków o udzielenie azylu ${ }^{23}$. Podobne stanowisko wobec

20 33. Ordentliche Bundesdelegiertenkonferenz am 25.-27. November 2011 in Kiel, Die Zukunft ist Europa, s. 5, [online] https://www.gruene.de, 9 X 2017.

21 System dubliński kształtował się stopniowo. Na początku obowiązywała Konwencja dublińska podpisana 15 czerwca 1990 r. przez rządy państw członkowskich w stolicy Irlandii (weszła w życie 1 września 1997 r.). W ramach procesu implementacji traktatu amsterdamskigo oraz związanego z tym uwspólnotowiania polityki azylowej 18 lutego 2003 r. konwencję zastąpiło rozporządzenie Rady Unii Europejskiej, określające kryteria i procedury postępowania państwa członkowskiego Unii, odpowiedzialnego za rozpatrzenie wniosku azylowego osoby z państwa trzeciego (Dublin II). Natomiast w ramach procesu implementacji traktatu lizbońskiego Parlament Europejski i Rada Unii Europejskiej 26 czerwca 2013 r. przyjęły nowe rozporządzenie (Dublin III), zastępujące i doprecyzowujące dotychczasowe przepisy. Szerzej na temat konwencji jako instrumentu prawnego w III filarze Unii Europejskiej por. J.J. Węc, Spór o ksztatt ustrojowy Wspólnot Europejskich i Unii Europejskiej 1950-2010. Między idea ponadnarodowości a wspótpraca międzyrządowa. Analiza politologiczna, Kraków 2012, s. 223-224, 282, Societas - Ksiegarnia Akademicka, 41. Szerzej na temat implementacji traktatu lizbońskiego por. J.J.Węc, Traktat Lizboński. Polityczne aspekty reformy ustrojowej Unii Europejskiej w latach 2007-2016, Krakow 2016, s. 295-346, Societas - Księgarnia Akademicka, 36. W niektórych dokumentach UE określenie Dublin I odnosi się do rozporządzenia Rady Unii Europejskiej z 18 lutego 2003 r., zaś Dublin II - do rozporządzenia Parlamentu Europejskiego i Rady Unii Europejskiej z 26 czerwca 2013 r., por. Komisja Europejska, Kryzys związany z uchodźcami. Zdecydowane działania Komisji Europejskiej. Pytania i odpowiedzi, Strasburg, 9 IX 2015, s. 1-6, [online] http://europa.eu/ rapid/press-release_MEMO-15-5597, 9 X 2017. Na temat ustalania prawa do azylu oraz gwarancji proceduralnych w sprawach dotyczących azylu i powrotu por. Handbook on European law relating to asylum, borders and immigration, Luxembourg 2014, s. 61-115.

22 34. Ordentliche Bundesdelegiertenkonferenz am 16.-18. November 2012 in Hannover, Beschlüsse, Europa ensteht durch Taten, s. 7, [online] https://www.gruene.de, 9 X 2017.

23 Ordentlicher Bundesparteitag der SPD am 4.-6. Dezember 2011 in Berlin, Übersicht der angenommenen und überwiesenenen Anträge, s. 169, [online] https://www.spd.de, 9 X 2017. 
Frontexu wyrażali reprezentanci Związku Powiatowego Würzburga ${ }^{24}$. Natomiast delegaci dystryktu Eimsbüttel-Süd (Związek Krajowy Hamburga) postulowali m.in. wprowadzenie ułatwień w uzyskaniu niemieckiego obywatelstwa lub podwójnego obywatelstwa przez migrantów, poprawę ich warunków kształcenia oraz ustanowienie licznych udogodnień w procedurach azylowych ${ }^{25}$. Te oddolne inicjatywy polityków SPD nie zostały jednak przyjęte jako uchwały Zjazdu Federalnego, lecz przekazane do rozpatrzenia innym gremiom partyjnym: frakcji parlamentarnej SPD w Bundestagu (wnioski Eimsbüttel-Süd i Münster), Zarządowi Federalnemu SPD (wnioski Münster i Würzburg) oraz frakcji Postępowego Sojuszu Socjalistów i Demokratów w Parlamencie Europejskim (wnioski Münster i Würzburg) ${ }^{26}$.

Za zmianami w polityce azylowej Unii Europejskiej opowiadała się również Lewica. W swoim programie przyjętym podczas Zjazdu Federalnego w dniach 21-23 października 2011 r. w Erfurcie krytycznie oceniła ona unijne ograniczenia w przyjmowaniu azylantów, nazywając je nawet polityką wykluczenia (Abschottungspolitik). Jej zdaniem ochrona praw człowieka, względy humanitarne oraz pomoc migrantom znajdującym się w potrzebie, a nie aspekty polityczne i ekonomiczne, winny stanowić fundament polityki azylowej Unii Europejskiej. Dlatego pierwszym krokiem prowadzącym do zmian w tej dziedzinie powinna być likwidacja Frontexu, stanowiacego najważniejszy instrument wykluczenia $U E^{27}$.

Zanim jeszcze 17 grudnia 2013 r. zaprzysiężony został trzeci gabinet Angeli Merkel, CDU/CSU i SPD w podpisanej kilka dni wcześniej umowie koalicyjnej uznały, że w obliczu wzrastającej w całym świecie nowej fali imigracji rząd federalny powinien uchwalić Strategię migracji i rozwoju, której celem byłoby wzmocnienie spójności działań w polityce zagranicznej, imigracyjnej i rozwojowej RFN. Strategia taka winna przyczynić się do skuteczniejszego zarządzania napływem migrantów i zwalczania pierwotnych przyczyn migracji we współpracy z krajami pochodzenia oraz państwami tranzytowymi ${ }^{28}$. Partie koalicyjne wskazały również na konieczność zmiany prawa azylowego RFN, w tym m.in. na skrócenie procedur azylowych do maksymalnie trzech miesięcy w przypadku wydawania pierwszych decyzji, oraz zapowiedziały wzmocnienie składu osobowego BAMF ${ }^{29}$. Opowiedziały się także za nadaniem Bośni-Hercegowinie, Macedonii i Serbii statusu krajów bezpiecznych w myśl \$29a Ustawy o azylu z 26 czerwca 1992 r. ${ }^{30}$ oraz za zachęceniem tamtejszych rządów i Komisji Euro-

\footnotetext{
Tamże.

25 Tamże, s. 166-167.
}

26 Tamże, s. 166-167, 169.

27 Program der Partei Die Linke, Beschluss des Parteitages der Partei Die Linke vom 21. bis 23. Oktober 2011 in Erfurt, s. 52, [online] https://www.die-linke.de, 9 X 2017.

28 Deutschlands Zukunft gestalten, Koalitionsvertrag zwischen CDU, CSU und SPD, 18. Legislaturperiode, Berlin, 14 XII 2013, s. 77.

29 Tamże, s. 76-77.

30 Asylgesetz (AsylG) in der Fassung der Bekanntmachung vom 2. September 2008 (BGBl. I, S. 1798), das zuletzt durch Art. 2 Abs. 2 des Gesetzes vom 4. November 2016 (BGBl. I, S. 2460) geändert worden ist, Bundesgesetzblatt, 2008, Teil 1, Nr. 40, Bonn, 8 VIII 2008. 
pejskiej do podjęcia działań w celu poprawy sytuacji społeczno-ekonomicznej w tych krajach. Zaapelowały one jednocześnie do władz Frontexu, aby w pracach mających na celu ochronę granic zewnętrznych konsekwentnie przestrzegaty standardów humanitarnych $i[. .$.$] praw cztowiek a^{31}$. Niezależnie od umowy koalicyjnej SPD w uchwalonym przez siebie programie działania rządu na lata 2013-2017 zapowiedziała podjęcie starań zmierzających w kierunku zmiany polityki azylowej Unii Europejskiej w sposób odpowiadający bardziej niż dotąd standardom ochrony praw cztowieka oraz zapewniający sprawiedliwy podziat odpowiedzialności za [...] integrację uchodźców we wszystkich państwach członkowskich Unii ${ }^{32}$.

W podobnym tonie wypowiadała się partia opozycyjna Sojusz 90/Zieloni. W programie wyborczym uchwalonym w czasie obrad Federalnej Konferencji Delegatów w dniach 26-28 kwietnia 2013 r. w Berlinie krytycznie oceniła ona dotychczasową politykę wobec uchodźców, realizowaną przez Unię Europejską i państwa członkowskie, określając ją - podobnie jak Lewica - jako „politykę wykluczenia”. Jej zdaniem Unia naruszała w ten sposób zakaz odmowy wynikający z konwencji genewskiej w sprawie statusu uchodźców z 28 lipca 1951 r. Dlatego ponownie zażądała zmiany art. 13 rozporządzenia Dublin II. Proponowała również ustanowienie „wysokich standardów azylowych", jednolitych we wszystkich państwach członkowskich Unii, wsparcie krajów najbardziej dotkniętych napływem migrantów, a także otwarcie się na uchodźców z Syrii oraz udzielenie pomocy finansowej tamtejszym państwom ościennym, które przyjęły już milionowe rzesze syryjskich uchodźców ${ }^{33}$.

Pierwsze oficjalne stanowiska partii chadeckich w sprawie wzrastającego napływu migrantów do Unii Europejskiej uchwalone zostały dopiero w 2014 r. O ile jednak reakcja CDU na te wydarzenia była nadal powściągliwa, o tyle opinie CSU były o wiele bardziej stanowcze. 5 kwietnia tegoż roku podczas Zjazdu Federalnego CDU w Berlinie przyjęto uchwałę, w której partia ta wyraziła zadowolenie z ustanowienia w 2013 r. WESA jako jednego z najnowocześniejszych na świecie. Uznała, że system dubliński zasadniczo się sprawdzit, choć staje się on niewydolny w przypadku zbyt dużego napływu migrantów do państw położonych na granicach zewnętrznych Unii Europejskiej. Z drugiej strony CDU zadeklarowała, że Republika Federalna będzie nadal wspierać finansowo działalność UNHCR oraz zgodzi się na przyjęcie migrantów z państw trzecich, jeżeli ich szybki powrót do krajów pochodzenia nie bytby możliwy lub nie byliby oni $w$ stanie $w$ petni zintegrować się $w$ tychże państwach. CDU zaapelowała również do pozostałych państw członkowskich Unii Europejskiej o przyjmowanie uchodźców ${ }^{34}$.

31 Deutschlands Zukunft gestalten, s. 76-77.

32 Das Wir entscheidet, Das Regierungsprogramm 2013-2017, Berlin 2013, s. 57-58, 112.

33 35. Ordentliche Bundesdelegiertenkonferenz vom Bündnis 90/Die Grünen vom 26.-28. April 2013 in Berlin, Zeit für den Grünenwandel, Teilhaben, Einmischen, Zukunft schaffen, Bundestagswahlprogramm 2013 von Bündnis 90/Die Grünen, Berlin 2013, s. 232-233.

34 26. Bundesparteitag der CDU Deutschlands am 5. April 2014 in Berlin, „Gemeinsam erfolgreich in Europa”. Europapolitischer Beschluss des 26. Parteitages der CDU Deutschlands, Berlin 2014, s. 84$-86$. 
Z kolei CSU podczas Zjazdu Krajowego w dniach 12-13 grudnia 2014 r. w Norymberdze przyjęła uchwałę, w której stwierdzała, że Unia Europejska winna być nadal kotwica stabilizacji na świecie. Jednak wzrastajacy ustawicznie naptyw uchodźców do Europy zagraża zarówno stabilności Unii, jak i Niemiec. W obliczu aktualnych kryzysów i zagrożeń Unia potrzebuje więcej Europy w dużym i mniej Europy w matym (mehr Europa im Großen und weniger Europa im Kleinen). Oznaczało to, że zacieśnianie współpracy między państwami członkowskimi winno dotyczyć najpoważniejszych zagrożeń płynących z zewnątrz, w tym także masowego napływu migrantów. Natomiast ograniczenie takiej współpracy powinno odnosić się do tych aspektów życia publicznego, z którymi lepiej radzą sobie państwa członkowskie. Najwyższym priorytetem w działaniach zewnętrznych Unii, ale także w politykach odpowiedzialnych za jej bezpieczeństwo wewnętrzne, winno być przezwyciężenie masowego napływu migrantów. W ślad za tym CSU proponowała rozszerzenie dotychczasowej działalności Unii Europejskiej o następujące zadania: po pierwsze wprowadzenie nowych przepisów azylowych w celu zagwarantowania sprawiedliwego podziatu uchodźców w państwach cztonkowskich UE, np. według obowiazkowego dla wszystkich systemu kwotowego (Verteilungsschlüssel); po drugie opracowanie specjalnego programu pomocowego dla uchodźców w wysokosci 1 mld euro; po trzecie zwiększenie zasięgu i intensywności operacji poszukiwawczo-ratowniczej Tryton oraz wzmocnienie kontroli granic zewnętrznych Unii; po czwarte rozważenie w sytuacjach nadzwyczajnych możliwości przywrócenia kontroli na granicach wewnętrznych Unii; po piąte skuteczniejsze zwalczanie sieci przemytników oraz handlu ludźmi ${ }^{35}$. Warto zauważyć, że CSU była pierwszą niemiecką partią polityczną, która zaproponowała system kwotowy jako metodę solidarnego podziału odpowiedzialności za uchodźców w Unii Europejskiej. Metoda ta była dotąd stosowana w RFN w postaci tzw. klucza z Königstein (Königsteiner Schlüssel), zgodnie z którym liczba azylantów przypadających na dany kraj federacji była obliczana co roku na podstawie jego wpływów podatkowych $(2 / 3)$ oraz liczby ludności $(1 / 3)^{36}$.

\section{Druga faza kryzysu (2015-2016)}

Pierwszą niemiecką partią polityczną, która bardzo ostro zareagowała na masowy napływ migrantów w 2015 r. do Unii Europejskiej, była FDP. Z powodu przegranych wyborów federalnych w 2013 r., pierwszej w historii Republiki Federalnej Niemiec absencji tej partii w Bundestagu oraz przejęcia roli opozycji pozaparlamentarnej było jej dość łatwo dystansować się od swojego powściągliwego stanowiska wobec kryzysu migracyjnego Unii, reprezentowanego w ramach koalicji rządowej z partiami chadeckimi

35 Parteitag der Christlich-Sozialen Union am 12.-13. Dezember 2014 in Nürnberg, Beschlüsse, Außenpolitik-Sicherheit-Europa, s. 4-5, [online] http://www.csu.de, 9 X 2017.

36 Nazwa systemu kwotowego podziału azylantów w RFN wywodzi się od miasta Königstein w Hesji, gdzie 31 marca 1949 r. kraje federacji podpisały porozumienie w sprawie podziału odpowiedzialności finansowej za działalność instytucji naukowo-badawczych w RFN. Później system ten był stosowany $\mathrm{w}$ innych dziedzinach życia publicznego, a tym w polityce azylowej, por. Königsteiner Schlüssel, s. 1, [online] http://www.gwk-bonn.de/themen/koenigsteiner-schluessel, 21 IV 2017. 
w latach 2009-2013. Nakazem chwili stało się wręcz dążenie do nadania FDP nowego profilu w czasie debaty publicznej w Niemczech na temat kryzysu migracyjnego Unii.

16 maja 2015 r. Zjazd Federalny FDP przyjął uchwałę w sprawie polityki imigracyjnej i azylowej RFN, która wytyczyła kierunki działań partii w drugiej fazie kryzysu migracyjnego Unii Europejskiej. FDP wzywała w niej do większego otwarcia się Niemiec na bieżące wyzwania migracyjne w Europie i na świecie oraz traktowania ich nie jako zagrożenie, lecz szansę dla demograficznego i gospodarczego rozwoju kraju. Niemcy winny - jej zdaniem - odgrywać rolę magnesu przyciagajacego wykwalifikowanych i gotowych do integracji ze spoteczeństwem niemieckim migrantów z catego świata, tym bardziej że zmiany demograficzne, w tym m.in. spadek przyrostu naturalnego oraz starzenie się społeczeństwa, spowodują, iż w 2050 r. może zabraknąć w Niemczech $15 \mathrm{mln}$ rąk do pracy ${ }^{37}$. Z drugiej strony jednak FDP opowiedziała się w swojej uchwale za gruntownymi zmianami w polityce imigracyjnej i azylowej Unii Europejskiej, w tym także za wprowadzeniem mechanizmu automatycznego podziału migrantów pomiędzy wszystkie państwa członkowskie na wzór obowiązującego w Niemczech tzw. klucza z Königstein ${ }^{38}$. Dlatego celem polityki Unii Europejskiej winno być większe otwarcie na uchodźców oraz sprawiedliwa ich relokacja, opierająca się na następujących kryteriach: liczbie ludności, wysokości PKB, stopie bezrobocia oraz wielkości danego państwa ${ }^{39}$.

17 czerwca 2015 r. Zarząd Federalny FDP opowiedział się za zastąpieniem rozporządzenia Dublin III przez nowe regulacje prawne, przewidujące ustanowienie kwotowego systemu podziału migrantów. Jednocześnie domagał się on zapewnienia legalnym migrantom dostępu do unijnego rynku pracy, wprowadzenia przyznawanej przez ambasady Unii Europejskiej tzw. wizy humanitarnej dla uchodźców pochodzących z krajów, w których ludność narażona jest na największe prześladowania, zwalczania pierwotnych przyczyn migracji w krajach pochodzenia, a także wsparcia procesów stabilizacji politycznej i ekonomicznej w państwach tranzytowych takich jak Libia ${ }^{40}$. Nieco ponad dwa miesiące później, 26 sierpnia 2015 r., Prezydium FDP w swoim dziesięciopunktowym programie powtórzyło wspomniany wyżej postulat rewizji rozporządzenia $\mathrm{Du}$ -

37 66. Ordentlicher Bundesparteitag der FDP am 16. Mai 2015 in Berlin, Beschlüsse. Für ein weltoffenes Deutschland - die Einwanderungs- und Flüchtlingspolitik der Freien Demokraten, s. 1-2, [online] http://www.fdp.de, 9 X 2017. Por. też uchwałę Zarządu Federalnego FDP z 15 stycznia 2015 r., w której partia ta opowiedziała się za opracowaniem nowoczesnej koncepcji polityki imigracyjnej RFN, por. Für ein zeitgemäßes Einwanderungskonzept, Beschluss des Bundesvorstands der FDP vom 19. Januar 2015 in Berlin, s. 1-4, [online] http://www.fdp.de, 9 X 2017.

3828 kwietnia 2016 r. również frakcja parlamentarna Sojusz 90/Zieloni złożyła wniosek w sprawie ustanowienia mechanizmu automatycznego podziału migrantów w UE na wzór tzw. klucza z Königstein. Wniosek został wtedy odesłany do parlamentarnej komisji spraw wewnętrznych (s. 16460), zaś 24 czerwca tego roku z rekomendacji komisji odrzucony na forum plenarnym Bundestagu (s. 17859-17860), por. Deutscher Bundestag, Verhandlungen des Deutschen Bundestages, Stenographische Berichte, 18. Wahlperiode, 167. Sitzung am 28. April 2016, s. 16448-16449, 16460, 16459-16460, 17859-17860, [online] http://dip21.bundestag.de, 9 X 2017.

39 66. Ordentlicher Bundesparteitag der FDP am 16. Mai 2015 in Berlin, s. 7-8, 12.

40 Forderungen an den Flüchtlingsgipfel, Beschluss des Bundesvorstands der FDP vom 17. Juni 2015 in Berlin, s. 2, [online] http://www.fdp.de, 9 X 2017. 
blin III i zastąpienia go kwotowym systemem podziału migrantów według kryteriów przyjętych w majowej uchwale Zjazdu Federalnego. Ponadto zaproponowało ono m.in. ustanowienie przez Unię Europejską specjalnego funduszu wspierającego państwa najbardziej obciążone masowym napływem migrantów oraz liberalizację unijnego prawa imigracyjnego przez wprowadzenie wizy humanitarnej i wizy czasowego zatrudnienia (Job-Visa) obok dotychczasowej tzw. niebieskiej karty ${ }^{41}$.

Pierwszą wspólną reakcją partii koalicji rządowej CDU/CSU/SPD na masowy napływ migrantów w 2015 r. oraz decyzję kanclerz Merkel o tymczasowym zawieszeniu przepisów rozporządzenia Dublin III w odniesieniu do ludności syryjskiej były uchwalone 6 września 2015 r. zalecenia komitetu koalicyjnego (Koalitionsausschuss), czyli gremium złożonego z przewodniczących CDU, CSU, SPD, przewodniczących frakcji parlamentarnych CDU/CSU i SPD oraz właściwych rzeczowo ministrów rządu federalnego. Przyjęty podczas tego spotkania pakiet środków obejmował: pomoc dla krajów pochodzenia oraz państw tranzytowych, służącą przeciwdziałaniu przyczynom migracji; wsparcie działań Unii Europejskiej w walce z kryzysem migracyjnym; koordynację współpracy pomiędzy federacją, krajami federacji i gminami w polityce azylowej RFN ${ }^{42}$.

Pomoc dla krajów pochodzenia i państw tranzytowych miała polegać m.in. na finansowym i instytucjonalnym wspieraniu obozów uchodźczych w regionach kryzysu oraz na działaniach na rzecz stabilizacji i wzmacniania państwowości krajów upadających lub upadłych ${ }^{43}$. Wsparcie dla działań Unii Europejskiej w walce z kryzysem oznaczało przede wszystkim aprobatę dla wszystkich propozycji Komisji Europejskiej, które miały być przedmiotem obrad Rady Unii Europejskiej 14 września 2015 r., dotyczących: utworzenia hotspotów w Grecji i we Włoszech; solidarnego i sprawiedliwego podziatu oraz przyjęcia uprawnionych do azylu wysiedleńców przez państwa członkowskie Unii Europejskiej; ustalenia wspólnej unijnej listy bezpiecznych krajów pochodzenia; przeprowadzenia fundamentalnej reformy polityki azylowej i ustanowienia jednolitego prawa azylowego Unii; skutecznego zwalczania sieci przemytniczych; wsparcia finansowego i praktycznego dla państw członkowskich Unii, aktualnie najbardziej obciążonych skutkami kryzysu; wzmocnienia zaangażowania Unii w zwalczanie przyczyn migracji w głównych krajach pochodzenia ${ }^{44}$. Ponadto komitet koalicyjny podjął kilka ważnych decyzji określających kierunki zmian w polityce azylowej RFN. Zapowiedział, że w projekcie budżetu na rok 2016 rząd federalny przeznaczy dodatkowe 3 mld euro na pomoc dla uchodźców na szczeblu federacji oraz odda do dyspozycji krajów federacji i gmin dalsze 3 mld euro ${ }^{45}$. Jednostki policji zajmujące się uchodźcami oraz BAMF winny być wzmocnione pod względem personalnym i technicznym. Należało także zmienić ustawę

41 10. Punkte für eine bessere Flüchtlings- und Einwanderungspolitik. Beschluss des Präsidiums der FDP vom 26. August 2015 in Berlin, s. 4, [online] www.fdp.de, 9 X 2017.

Sitzung des Koalitionsausschusses am 6. September 2015, s. 1, [online] http://fluechtlingsrat-bw.de, 9 X 2017.

43 W związku z tym postanowiono znacząco zwiększyć przeznaczone na ten cel środki finansowe z budżetów Ministerstwa Spraw Zagranicznych oraz Ministerstwa do spraw Współpracy Gospodarczej i Rozwoju, por. tamże, s. 2.

44 Tamże, s. 2-3.

45 W 2015 r. federacja przeznaczyła na ten cel 1 mld euro, por. tamże, s. 6 . 
o bezpiecznych krajach pochodzenia, nadając taki status Albanii, Kosowu i Czarnogórze. Za niezwykle istotne uznano również: przyspieszenie postępowań azylowych oraz procedur powrotów; anulowanie dotychczasowego błędnego systemu zachęt finansowych dla migrantów (m.in. zastąpienie wypłat gotówkowych świadczeniami rzeczowy$\mathrm{mi}$ ); poprawę zasad integrowania się migrantów ze społeczeństwem niemieckim; rozbudowę budownictwa socjalnego; ustanowienie 10 tys. dodatkowych etatów w służbach wolontariatu; ułatwienie legalnej migracji zarobkowej jako alternatywy wobec azylu dla obywateli Albanii, Kosowa, Czarnogóry, Bośni-Hercegowiny, Serbii i Macedonii ${ }^{46}$.

Komitet koalicyjny zapowiedział również, że Niemcy wywiążą się ze swoich zobowiązań wobec azylantów, oraz wyraził nadzieję, że to samo uczynią pozostałe państwa członkowskie Unii Europejskiej ${ }^{47}$. Zapowiedź ta dotyczyła m.in. kontrowersyjnego w niektórych państwach Europy Środkowo-Wschodniej wniosku ustawodawczego Komisji Europejskiej z 9 września 2015 r. w sprawie ustanowienia stałego kryzysowego mechanizmu relokacji. Wniosek Komisji Europejskiej popierały zarówno frakcje koalicji rządowej, jak i opozycji parlamentarnej. Z drugiej strony jednak zarówno SPD, jak i Sojusz 90/Zieloni zarzucały, zwłaszcza partiom chadeckim, popełnienie poważnych błędów w polityce wobec uchodźców w pierwszej fazie kryzysu w latach 2011-2014. Przewodniczący frakcji parlamentarnej socjaldemokratów Thomas Oppermann argumentował, że cztery lata wcześniej, gdy kryzys dotyczył włoskiej wyspy Lampedusa i Grecji, CDU i CSU sprzeciwiały się ustanowieniu systemu kwotowego dla uchodźców, a teraz zmieniły zdanie, gdy Niemcy same znalazły się pod presją napływu migrantów ${ }^{48}$. Katrin Göring-Eckardt z Sojuszu 90/Zieloni oskarżyła ówczesne rządy, że do 2014 r. stosowały

46 Tamże, s. 3-7. Większość z tych postulatów znalazła się później w tzw. I pakiecie azylowym (Asylpaket I), który wszedł w życie 24 października 2015 r., choć niektóre przepisy zaczęły obowiązywać nieco później. Przewidywał on m.in. zmiany w: finansowaniu polityki azylowej przez federację i kraje federacji, rodzajach świadczeń (ograniczenie wypłat w gotówce na rzecz świadczeń rzeczowych), podziale migrantów na poszczególne kraje federacji, procesie integracji azylantów (kursy językowe, ułatwiony dostęp do rynku pracy), a także uznaniu Albanii, Kosowa i Czarnogóry za bezpieczne kraje pochodzenia. Przepisy te zostały wprowadzone w życie zasadniczo na mocy ustawy w sprawie przyspieszenia postępowania azylowego, por. Asylverfahrensbeschleunigungsgesetz vom 20. Oktober 2015, Bundesgesetzblatt, 2015, Teil I, Nr. 40, Bonn, 23. Oktober 2015. Ponadto 7 lipca 2016 r. Bundestag uchwalif ustawę integracyjną, która weszła w życie 6 sierpnia tegoż roku (część przepisów zaczęła obowiązywać od 1 stycznia 2017 r.). Ustawa przewiduje ułatwienia w procesie integracji azylantów ze społeczeństwem niemieckim, ale także stosowanie sankcji za jej nieprzestrzeganie. Ułatwienia dotyczą m.in. dostępu do kursów integracyjnych (nauka niemieckiego języka i kultury) oraz rynku pracy. Jednak uchodźcy, którzy przerwą kurs integracyjny, muszą się liczyć z obniżeniem świadczeń socjalnych. Prawo do stałego pobytu będzie przysługiwało po pięciu latach, zamiast dotychczasowych trzech lat, i będzie uwarunkowane wystarczającą znajomością języka niemieckiego oraz zdolnością do samodzielnego utrzymania. Po trzech latach azylanci otrzymają natomiast takie prawo, gdy będą znać język niemiecki oraz posiadać pracę. W celu równomiernego rozłożenia ciężaru utrzymania azylantów oraz przeciwdziałania skupianiu się ich w największych metropoliach (Ballungsgebiete) ustawa przewiduje także możliwość wyznaczenia im miejsca zamieszkania przez kraje federacji, por. Integrationsgesetz vom 31. Juli 2016, Bundesgesetzblatt, 2016, Teil I, Nr. 39, Bonn, 5. August 2016.

47 Sitzung des Koalitionsausschusses am 6. September 2015, s. 1.

48 Deutscher Bundestag. Verhandlungen des Deutschen Bundestages. Stenographische Berichte. 18. Wahlperiode. 145. Sitzung am 16. Dezember 2015, s. 14287, [online] http://dip21.bundestag.de/, 9 X 2017. 
one zasadęśw. Floriana w polityce wobec uchodźców, co doprowadziło tylko do spotęgowania kryzysu. Posługiwanie się tą zasadą miało polegać na tym, że rząd federalny chciał rozwiązać kryzys migracyjny możliwie najdalej od granic Niemiec, najlepiej w krajach pochodzenia lub państwach ościennych, ale w każdym razie poza Unia Europejska ${ }^{49}$. Niektórzy socjaldemokraci, jak minister ds. gospodarki i energii oraz przewodniczący SPD Sigmar Gabriel, otwarcie wskazywali jednakże na zapotrzebowanie Niemiec na siłę roboczą. Gabriel argumentował, że rząd federalny powinien być zainteresowany napływem migrantów, ponieważ do 2030 r. niemiecki rynek pracy skurczy się aż o $6 \mathrm{mln}$ osób i właśnie migranci przybywający obecnie do Republiki Federalnej moga [...] pomóc to zmienić. W przeciwnym razie powstanie realne zagrożenie nie tylko dla przedsiębiorców, lecz także dla dobrobytu całego niemieckiego społeczeństwa ${ }^{50}$.

5 listopada 2015 r. przewodniczący partii koalicji rządowej CDU/CSU/SPD przyjęli specjalną uchwałę w sprawie kryzysu migracyjnego. W dużej mierze, zwłaszcza w części dotyczącej działań Unii Europejskiej na rzecz zwalczania kryzysu, opierała się ona na wspólnym stanowisku (Positionspapier) partii chadeckich sprzed czterech dni ${ }^{51}$. Merkel, Seehofer i Gabriel powtórzyli w podpisanej przez siebie uchwale dotychczasowe postulaty rządu federalnego w sprawie reformy polityki imigracyjnej i azylowej Unii Europejskiej, w tym m.in. konieczność ustanowienia systemu kwotowego (Strukturen der Lastenteilungen), utworzenia hotspotów w Grecji i we Włoszech oraz nadania większej efektywności mechanizmowi powrotów nielegalnych migrantów do krajów pochodzenia. Z drugiej strony, wychodząc naprzeciw nowym priorytetom Unii Europejskiej w walce z kryzysem, poparli oni inicjatywę zawarcia porozumienia z Turcją oraz działania na rzecz uszczelnienia granic zewnętrznych Unii ${ }^{52}$.

W części dotyczącej niemieckiej polityki azylowej przewodniczący CDU, CSU i SPD opowiedzieli się natomiast za następującymi zmianami: wprowadzeniem dowodu uchodźcy i banku danych starających się o azyl w tzw. normalnym postępowaniu azylowym; ustanowieniem od trzech do pięciu centrów dla migrantów z małymi szansami na przyznanie azylu oraz zaostrzeniem reżimu rezydencjalnego $w$ tzw. przyspieszonym postępowaniu azylowym; zawieszeniem na dwa lata prawa azylantów do łączenia rodzin; wprowadzeniem obowiązku współfinansowania przez uchodźców kosztów procesu ich integracji ze społeczeństwem niemieckim; ustanowieniem federalnego centrum ds. kontaktów z ambasadami krajów pochodzenia w celu ułatwienia identyfikacji migrantów; ograniczeniem jedynie do ciężkich przypadków chorobowych prawa do odwlekania przez nielegalnych migrantów możliwości wydalenia z Niemiec ${ }^{53}$.

49 Deutscher Bundestag. Verhandlungen des Deutschen Bundestages. Stenographische Berichte. 18. Wahlperiode. 120. Sitzung am 9. September 2015, s. 11616, [online] http://dip21.bundestag.de/, 9 X 2017.

Deutscher Bundestag. Verhandlungen des Deutschen Bundestages. Stenographische Berichte. 18. Wahlperiode. 121. Sitzung am 10. September 2015, s. 11703, [online] http://dip21.bundestag.de/, 9 X 2017.

51 Menschen in Not helfen, Zuwanderung ordnen und steuern, Integration sichern. Positionspapier von CDU und CSU vom 1. November 2015, Berlin, 1. November 2015, s. 1-6.

52 Beschluss der Parteivorsitzenden von CDU, CSU und SPD, Berlin, 5. November 2015, s. 5-7.

53 Tamże, s. 1-5. Większość z tych propozycji znalazła swoje odzwierciedlenie w tzw. II pakiecie azylowym, który wszedł w życie 17 marca 2016 r. Przewiduje on m.in. zawieszenie na dwa lata prawa 
Podczas gdy uchwała przewodniczących CDU, CSU i SPD z 5 listopada 2015 r. określiła stanowisko rządu federalnego wobec nowych priorytetów Unii Europejskiej $\mathrm{w}$ walce $\mathrm{z}$ kryzysem migracyjnym, to podstawowym dokumentem $\mathrm{w}$ dużej mierze definiującym działania partii chadeckich było wspomniane wyżej stanowisko CDU i CSU z 1 listopada tegoż roku ${ }^{54}$. Nawiązywały do niego wszystkie ważniejsze dokumenty programowe partii chadeckich, przyjęte w następnych kilkunastu miesiącach, takie jak: deklaracja Zjazdu Federalnego CDU z 15 grudnia 2015 r., uchwała Zjazdu Federalnego CDU z 7 grudnia 2016 r., uchwała Zjazdu Krajowego CSU z 21 listopada 2015 r., uchwała Zarządu Krajowego CSU z 10 września 2016 r. oraz program zasadniczy CSU przyjęty podczas Zjazdu Krajowego tej partii 5 listopada tegoż roku.

O ile w deklaracji z 15 grudnia 2015 r. CDU potwierdziła zasadniczo wszystkie dotychczasowe cele i zadania partii w walce $\mathrm{z}$ kryzysem $^{55}$, o tyle w uchwale $\mathrm{z} 7$ grudnia 2016 r. pozytywnie oceniła nadto podpisanie i realizację wspomnianej niżej umowy z Turcją z 18 marca tegoż roku, zamknięcie wschodniego szlaku śródziemnomorskiego dla migrantów, wzmocnienie i uszczelnienie granic zewnętrznych Unii Europejskiej, a także wszczętą 4 maja 2016 r. przez Komisję Europejską reformę rozporządzenia Dublin III. Z drugiej strony opowiedziała się w niej za utworzeniem na granicach państw członkowskich stref tranzytowych dla migrantów oczekujących na rozpatrzenie wniosków azylowych, za harmonizacją standardów socjalnych dla azylantów, a także za podpisaniem porozumień z państwami afrykańskimi w sprawie współpracy w zwalczaniu nielegalnej migracji na wzór umowy między Unią Europejską a Turcją ${ }^{56}$. Inaczej niż CDU jej siostrzana partia CSU wychodziła w swoich dokumentach programowych poza ramy przyjęte w rezolucji z 1 listopada 2015 r. Jej stanowisko wobec kryzysu migracyjnego oraz samych azylantów było o wiele bardziej ambiwalentne, ale także bardziej realistyczne. Podobnie jak w pierwszej fazie kryzysu w latach 2011-2014 partia ta w pełni dostrzegała bowiem zagrożenia wynikające z masowego napływu migrantów zarówno dla Unii Europejskiej, jak i dla Niemiec. Dlatego w swoim programie

azylantów do łączenia rodzin, z wyjątkiem członków rodzin znajdujących się w obozach dla uchodźców w Turcji, Jordanii i Libanie; wprowadzenie obowiązku współfinansowania kosztów procesu integracji przez uchodźcę w wysokości 10 euro na miesiąc; uznanie Maroka, Algierii i Tunezji za bezpieczne kraje pochodzenia; ograniczenie jedynie do ciężkich przypadków chorobowych prawa do odwlekania przez nielegalnych migrantów możliwości wydalenia z Niemiec; ustanowienie pięciu centrów dla migrantów z małymi szansami na udzielenie azylu, co dotyczyło osób nieokazujących gotowości do współpracy lub podających fałszywe dane na temat własnej tożsamości, lub niszczących świadomie własne dokumenty, lub pochodzących z tzw. krajów bezpiecznych, lub mających zakaz wjazdu do RFN, por. Gesetz zur Einführung beschleunigter Asylverfahren vom 11. März 2016; Bundesgesetzblatt, 2016, Teil I, Nr. 12, Bonn, 16. März 2016; Gesetz zur erleichterten Ausweisung von straffäligen Ausländern und zum erweiterten Ausschluss der Flüchtlingsanerkennung bei straffäligen Asylbewerbern vom 11. März 2016, Bundesgesetzblatt, 2016, Teil I, Nr. 12, Bonn, 16. März 2016.

54 Menschen in Not helfen, Zuwanderung..., s. 1-6.

55 28. Bundesparteitag der CDU am 14.-15. Dezember 2015 in Karlsruhe. Beschlüsse. Karlsruher Erklärung zu Terror und Sicherheit, Flucht und Integration, s. 8-23, [online] http://www.cdu.de, 9 X 2017.

56 29. Bundesparteitag der CDU am 6.-7. Dezember 2016 in Essen. Beschlüsse. Orientierung in schwieriegen Zeiten - für ein erfolgreiches Deutschland und Europa, s. 13-19, [online] http://www.cdu.de, $9 \times 2017$. 
przyjętym podczas Zjazdu Krajowego w dniach 20-21 listopada 2015 r. w Monachium apelowała do wszystkich państw członkowskich o przestrzeganie prawa Unii Europejskiej w polityce migracyjnej i azylowej, w szczególności zaś przepisów rozporządzenia Dublin III czy też dorobku prawnego Schengen. Podobnie jak dotąd opowiadała się także za wprowadzeniem kwotowego systemu podziału migrantów ${ }^{57}$. Z drugiej strony jednak przestrzegała samych uchodźców przed próbami ustanawiania społeczeństwa multikulturowego w Niemczech czy wręcz gettoizacji (Ghettoisierung) Niemiec lub przed szerzeniem religijnego fundamentalizmu i fanatyzmu. Przypominała, że w Niemczech obowiązuje Ustawa Zasadnicza, a nie prawo szariatu. W ślad za tym przeciwstawiała koncepcji społeczeństwa multikulturowego ideę „kultury wiodącej” (Leitkultur), obejmującej zachodnia tradycję chrześcijańsko-judaistyczna, nasze podstawowe wartości, niemiecki język, nasza historię i kulturę. Przestrzeganie niemieckiego prawa jest oczywistością, ale „prawdziwa wspólnota” potrzebuje czegoś więcej. Czymś takim jest

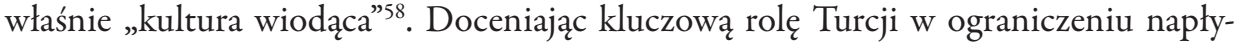
wu migrantów wschodnim szlakiem śródziemnomorskim do Unii Europejskiej, CSU nadal sprzeciwiała się jej akcesji do Unii i proponowała zamiast tego status uprzywilejowanego partnera dla tego państwa ${ }^{59}$. W uchwale Zarządu Krajowego z 10 września 2016 r. CSU zapowiadała, że Bawaria nadal pełnić będzie w Niemczech funkcję kraju federacji wyznaczającego trendy (Taktgeber) w walce z kryzysem migracyjnym oraz w procesie integracji azylantów, podstawą której winna być „kultura wiodąca”. W ślad za tym domagała się wprowadzenia tego ostatniego pojęcia do konstytucji Bawarii ${ }^{60}$ oraz ustawowego określenia górnej granicy dla liczby przyjmowanych uchodźców w Niemczech na 200 tys. osób rocznie. CSU sprzeciwiała się także zniesieniu kontroli na granicy z Austrią do czasu przywrócenia rzeczywistej ochrony granic zewnętrznych Unii Europejskiej. Krytycznie oceniając decyzję kanclerz Merkel o otwarciu tej granicy

57 Parteitag der Christlich-Sozialen Union am 20.-21. November 2015 in München. Beschlüsse. Deutschland braucht das starke Bayern. Migration-Leikultur-Integration, s. 28, [online] http://www. csu.de, 9 X 2017.

Tamże, s. 30-31.

Tamże, s. 30.

6030 kwietnia 2017 r. minister spraw wewnętrznych de Maizière (CDU) w artykule opublikowanym na łamach „Bild am Sonntag” poparł ideę „kultury wiodącej” rozumianej jako warunek udanej integracji migrantów z niemieckim społeczeństwem oraz wezwał do publicznej debaty na ten temat. Propozycja ta została natychmiast oprotestowana przez polityków SPD, FDP i Sojuszu 90/Zielonych. Socjaldemokratyczny kandydat na kanclerza Martin Schulz uznał ją za absurdalną, argumentując, że „niemiecką kulturą wiodącą jest wolność, sprawiedliwość i dobre współżycie ze sobą, jak to określa Ustawa Zasadnicza”. Przewodniczący FDP Christian Lindner zarzucił de Maizière'owi uprawnianie kampanii wyborczej. Natomiast współprzewodnicząca Sojuszu 90/Zielonych Simone Peter stwierdziła, że Niemcy nie potrzebują żadnej debaty na temat „kultury wiodącej”, lecz „nowej polityki wewnętrznej, która ułatwia integrację, monitoruje prawicowe ugrupowania (rechte Netzwerke) i zdaje sobie sprawę z zagrożenia islamistycznego", por. De Maizière stößt mit Vorschlägen zur Leitkultur auf Kritik, 30. April 2017, s. 1, [online] http://www.bild.de, 9 X 2017. De Maiziëre stellt zehn Thesen zur deutschen Leitkultur auf, 30. April 2017, s. 1, [online] http://www.sueddeutsche.de. De Maizière erntet mit seinem Vorstoß zur Leitkultur Kritik, 1. Mai 2017, s. 1-2, [online] http://www.sueddeutsche.de, $9 \times 2017$. 
we wrześniu 2015 r., stanowczo stwierdzała, że $w$ żadnym razie nie może dojsć do powtórzenia się sytuacji, jaka miała wówczas miejsce, ponieważ żadne państwo nie może tolerować nielegalnego przekraczania swoich granic ${ }^{61}$. Uchwały przyjęte przez Zjazd Krajowy w 2015 r. oraz Zarząd Krajowy CSU w 2016 r. miały fundamentalnie znaczenie dla tej partii w walce z kryzysem migracyjnym, o czym świadczył fakt, że najważniejsze $\mathrm{z}$ ich postanowień zostały włączone do programu zasadniczego przyjętego 5 listopada 2016 r. podczas Zjazdu Krajowego w Monachium ${ }^{62}$.

\section{WPŁYW RZĄDU FEDERALNEGO NA REFORMĘ POLITYKI IMIGRACYJNEJ I AZYLOWEJ UNII EUROPEJSKIEJ. ZARZĄDZANIE KRYZYSEM CZY DZIAŁANIE W AFEKCIE?}

Mimo pełnej świadomości nadchodzącego zagrożenia, krytycznych ocen wobec dotychczasowej polityki imigracyjnej Unii Europejskiej oraz apeli o jej reformę, zarówno rząd koalicyjny CDU/CSU/SPD, jak i partie opozycji parlamentarnej zostały w pełni zaskoczone przez kryzys migracyjny, który wybuchł w 2015 r. w Unii Europejskiej. Żadna ze stron nie była przygotowana ani na tak masowy napływ migrantów w tak krótkim czasie, ani na bezradność Unii w obliczu kryzysu. Choć liczba wniosków o przyznanie azylu w Unii Europejskiej wzrosła w 2014 r. o ponad 45\% w porównaniu z rokiem $2013^{63}$, zaś w ciągu pierwszych ośmiu miesięcy 2015 r. wzrastała w jeszcze większym tempie, to rząd federalny nie dysponował wówczas nadal żadną skuteczną receptą przeciwdziałania presji migracyjnej ${ }^{64}$.

18 czerwca 2015 r. podczas wystąpienia w Bundestagu kanclerz Merkel zaapelowała do rządów wszystkich państw członkowskich Unii Europejskiej o solidarny udział w przyjmowaniu wysiedleńców zgodnie ze wspomnianym wyżej wnioskiem ustawodawczym Komisji Europejskiej z 27 maja tegoż roku w sprawie ustanowienia tymczasowego mechanizmu relokacji na korzyść Włoch oraz Grecji ${ }^{65}$. Powołując się na bieżące dane Eurostatu, Merkel stwierdziła również, że Niemcy nie mogą się zgodzić na to, aby jedynie pięć państw członkowskich (RFN, Węgry, Szwecja, Austria, Włochy) miało przyjąć aż $3 / 4$ wszystkich osób ubiegających się o azyl ${ }^{66}$.

${ }_{61}$ Klarer Kurs bei der Zuwanderung. Humanität, Ordnung, Begrenzung. Beschluss des CSU-Parteivorstandes vom 9./10. September 2016 in Schwarzenfeld, s. 1-10, [online] http://www.csu.de, 9 X 2017.

62 Parteitag der Christlich-Sozialen Union am 4.-5. November 2016 in München. Die Ordnung. Grundsatzprogramm der Christlich-Sozialen Union, s. 14-15, [online] http://www.csu.de, 9 X 2017.

63 O ile w 2013 r. złożono 431090 wniosków, o tyle w 2014 było ich aż 626960 , por. Eurostat. Asylum applicant, s. 1 .

64 Łączna liczba migrantów, którzy złożyli pierwsze i odwoławcze wnioski azylowe w 2015 r. w Niemczech, wyniosła w 2015 r. 476649 osób, czyli o 135\% więcej w porównaniu z 2014 r., por. tamże.

65 Deutscher Bundestag. Verhandlungen des Deutschen Bundestages. Stenographische Berichte. 18. Wahlperiode. 112. Sitzung am 18. Juni 2015, s. 10688, [online] http://dip21.bundestag.de/, 9 X 2017.

66 Asylum applicant, s. 1-2. 
Latem 2015 r. do stolicy Węgier, Budapesztu, zaczęly przybywać wschodnim szlakiem śródziemnomorskim tysiące migrantów. Rząd węgierski stanął w obliczu niezwykle trudnego dylematu. Każde rozwiązanie wydawało się niekorzystne. Przyjęcie uciekinierów przekraczało możliwości absorpcyjne tamtejszego systemu azylowego. Zgoda na wyjazd do Austrii czy Niemiec bez rozpatrzenia wniosku azylowego oznaczałaby natomiast nie tylko naruszenie przepisów rozporządzenia Dublin III, lecz także zachęciłaby kolejne rzesze migrantów do przybywania do Unii. Mimo to pod koniec sierpnia 2015 r. rząd premiera Viktora Orbána zezwolił wielu tysięcom migrantów na marsz autostradą z Budapesztu w kierunku Austrii, a nawet oddał do ich dyspozycji autokary. Pokerowe posunięcie Orbana zmusiło do działania rządy Austrii i Niemiec. 31 sierpnia 2015 r. podczas konferencji prasowej kanclerz Merkel wypowiedziała swoje słynne słowa - Damy radę! (Wir schaffen das!), które potem stały się symbolem polityki „otwartych drzwi" niemieckiego rządu stosowanej wobec wysiedleńców ${ }^{67}$.

W reakcji na marsz migrantów w kierunku Austrii w nocy z 4 na 5 września 2015 r. Merkel i kanclerz Austrii Faymann w porozumieniu z Orbánem ogłosili, wspomnianą wyżej, kontrowersyjną decyzję o czasowym zawieszeniu przepisów rozporządzenia $\mathrm{Du}$ blin III w odniesieniu do ludności syryjskiej ${ }^{68}$. Uzgodnili również, że autokary i pociągi z migrantami będą przepuszczane z Austrii do Bawarii. W efekcie tych ustaleń w następnym dniu niemiecką granicę przekroczyło aż ok. 12 tys. migrantów. Jednak już kilka godzin po podjęciu decyzji kanclerz Austrii alarmował Merkel, że uchodźców jest znacznie więcej, aniżeli się spodziewano ${ }^{69}$.

Decyzja Merkel została podjęta spontanicznie, bez zgody gabinetu rządowego, debaty parlamentarnej w Bundestagu i uchwały frakcji parlamentarnych CDU/CSU i SPD, a także bez zgody władz partyjnych koalicji rządowej. Napotkała ona ostrą krytykę zarówno w Niemczech, jak i w innych państwach członkowskich Unii Europejskiej. Głównym adwersarzem kanclerz w Republice Federalnej stała się współrządząca CSU. Premier Bawarii i zarazem przewodniczący CSU Seehofer ostrzegał, że jednym ze skutków niekontrolowanego napływu migrantów może być wzrost poparcia dla ugrupowań skrajnie prawicowych w Niemczech. Sekretarz generalny partii Andreas Scheuer informował, że Zarząd CSU jednomyślnie uznał wspomnianą decyzję Merkel za błędny sygnał. Postawę kanclerz skrytykował także minister spraw wewnętrznych Bawarii Joachim Herrmann ${ }^{70}$. Najwięcej słów krytyki z zagranicy popłynęło natomiast z państw

67 Kanclerz użyła tego sformułowania, bazując na szacunkach niemieckich urzędów, zgodnie z którymi do końca 2015 r. do RFN miało przybyć ok. 800 tys. migrantów, por. Merkels drei große kleine Worte, 31 VIII 2015, [online] https://www.tagesschau.de, 9 X 2017, s. 1. G. Banas, Flüchtlingsfrage. Merkel: „Wir schaffen das”, „Frankfurter Allgemeine Zeitung” 2015, 31 VIII, s. 1-2. Pierwszy raz liczbę taką podał 19 sierpnia 2015 r. minister spraw wewnętrznych de Maizière, por. Flüchtlingeprognose 2015. Bundesregierung rechnet mit bis zu 800.000 Asylbewerbern, 19 VIII 2015, s. 1, [online] http://www. spiegel.de/, 9 X 2017.

68 F. Trauner, Wie sollen Flüchtlinge..., s. 99.

69 Btędy Merkel w polityce wobec uchodźców. Chwilowe otwarcie granic catkowicie odmienito Niemcy, PAP, 17 III 2017, s. 1-2.

70 W Niemczech narasta napięcie. CSU krytykuje Merkel za chęć przyjęcia uchodźców. „To btędny sygnat”, PAP, 6 września 2015 r., s. 1-2. 
Europy Środkowo-Wschodniej, głównie Węgier i Polski ${ }^{71}$. Były one konsekwencją nie tylko kontrowersyjnej decyzji o zawieszeniu przepisów Dublin III w odniesieniu do ludności syryjskiej, lecz także późniejszych zabiegów dyplomatycznych rządu federalnego w sprawie wprowadzenia stałego kryzysowego mechanizmu relokacji dla wszystkich państw członkowskich Unii Europejskiej. Zabiegi te odbierano jako próbę przerzucenia na te kraje odpowiedzialności za błędy Niemiec w polityce azylowej i imigracyjnej ${ }^{72} .13$ września 2015 r. pod naporem coraz większych rzesz migrantów rząd federalny zmuszony był przywrócić kontrolę na granicy z Austrią, zaś w listopadzie tegoż roku ponownie zaczął przestrzegać postanowień rozporządzenia Dublin $\mathrm{III}^{73}$.

Już 6 września 2015 r. komitet koalicyjny wyznaczył - jak się wtedy wydawało - kierunki działań rządu federalnego na kilka najbliższych miesięcy. Przeprowadzona na forum komitetu dyskusja uspokoiła też napiętą dotąd atmosferę pomiędzy partiami chadeckimi. Uczestnicy posiedzenia uzgodnili, że decyzja, jaką w nocy z 4 na 5 września 2015 r. podjęli kanclerz RFN Merkel oraz kanclerz Austrii Faymann, nie powinna się powtórzyc ${ }^{74}$, co oznaczało de facto uznanie jej za błędną. Zalecenia komitetu koalicyjnego wywarły istotny wpływ na dalsze działania rządu federalnego w walce z kryzysem migracyjnym. Bazując na tym dokumencie, jego przedstawiciele brali udział w procedurze przyjęcia przez Radę Unii Europejskiej 14 i 22 września 2015 r. decyzji dotyczących relokacji migrantów z Włoch i Grecji. O ile uchwalenie decyzji z 14 września 2015 r. przebiegło dość gładko, o tyle przyjęcie decyzji z 22 września tegoż roku wywołało znaczące kontrowersje między poszczególnymi delegacjami. Podczas gdy pierwsza decyzja opierała się na dobrowolnych i przyjętych w drodze konsensu ustaleniach rządów państw członkowskich, zawartych jeszcze w rezolucji z 20 lipca tegoż roku ${ }^{75}$, to druga decyzja, przewidująca obowiązkowy system kwotowy, podjęta została kwalifikowaną

71 Angela Merkel broni decyzji o otwarciu granicy dla uchodźców z Syrii, 12 IX 2015, http://wiadomosci. onet.pl, 9 X 2017, s. 1; Niemieckie media: Merkel przyznaje się do btędu w sprawie uchodźców, s. 1-2, [online] http://www. newsweek.pl, 9 X 2017; PO i PiS jednym gtosem w sprawie imigrantów. Decyzje dopiero po wyborach, 1 IX 2015, s. 1, [online] http://www.gazetaprawna.pl/, 9 X 2017; Leszek Miller, Merkel jest największym szkodnikiem Europy, 15 XI 2015, s. 1, [online] https://pl.sputniknews.com/ polityka, 9 X 2017; Czy Niemcy zmuszą Polskę do przyjęcia 100 tysięcy uchodźców?, 24 VIII 2015, s. 1-2, [online] http://www.defence24.pl/, 9 X 2017; Angela Merkel czyli o zwyciestwie postpolityki, 21 X 2015, s. 1-3.

72 J. Bielecki, Merkel strzelita sobie gola, 21 października 2015 r., s. 1-2, [online] http://wiadomosci. wp.pl, 9 X 2017.

73 Oświadczenie Ministerstwa Spraw Wewnętrznych RFN por. Vorübergehende Wiedereinführung von Grenzkontrollen. De Maizière verkündet Wiedereinführung von Kontrollen an Binnengrenzen - Schwerpunkt vorerst Grenze zu Österreich, s. 1-2, [online] http://www.bmi.bund.de, 9 X 2017. F. Trauner, Wie sollen Fluchtlinge..., s. 99.

74 Sitzung des Koalitionsausschusses am 6. September 2015, s. 1, [online] http://www.fluechtlingsrat-bw.de, 9 X 2017.

75 Council of the European Union, Outcome of the Council Meeting (Justice and Home Affairs), Brussels, 14 IX 2015, 11969/15, s. 8; Council of the European Union, Conclusions, Brussels, 14 IX 2015, 12002/1/15, REV 1, s. 1-7; Rada Unii Europejskiej. Protokół z posiedzenia Rady Unii Europejskiej (ds. Wymiaru Sprawiedliwości i Spraw Wewnętrznych) w dniu 20 lipca 2015 r., Bruksela, 22 IX 2015, $11088 / 15$, s. 3-4. 
większością głosów (z udziałem Polski), ale wbrew woli Republiki Czeskiej, Słowacji, Węgier i Rumunii, zaś Finlandia wstrzymała się od głosu ${ }^{76}$.

Oficjalne stanowisko rządu federalnego wobec systemu kwotowego zostało sformułowane po raz pierwszy we wspólnym oświadczeniu Niemiec i Francji, załączonym do protokołu Rady Unii Europejskiej z 20 lipca 2015 r. W dokumencie tym rządy obu państw zadeklarowały, że przyjmą w ciągu dwóch lat uchodźców przebywających we Włoszech i w Grecji zgodnie z wnioskiem Komisji Europejskiej z 27 maja 2015 r. Jednak z drugiej strony w bardzo protekcjonalnym tonie zastrzegły sobie, iż będą bacznie przyglądać się, czy spełnione zostaną wszystkie pozostałe warunki uzgodnione w rezolucji, w szczególności zaś czy wszystkie państwa członkowskie objęte programem relokacji wezmą w nim udział, by osiagnać wyważony podziat wysitków ${ }^{77}$. Rządy Niemiec i Francji należały do tej grupy państw członkowskich, które najbardziej aktywnie zabiegały o stworzenie tymczasowego, a następnie od września 2015 r. także stałego kryzysowego mechanizmu relokacji dla całej Unii Europejskiej. Bazując na wspólnym stanowisku z Francją, kanclerz Merkel wprowadziła postulat solidarnego i sprawiedliwego podziału wysiedleńców do zaleceń komitetu koalicyjnego z 6 września 2015 r. Trzy dni później podczas debaty parlamentarnej w Bundestagu postulat ten poparły frakcje parlamentarne koalicji rządowej CDU/ CSU/SPD oraz opozycji parlamentarnej Sojuszu 90/Zielonych i Lewicy ${ }^{78}$.

Jak wspomniano, decyzja Rady Unii Europejskiej z 22 września 2015 r. w sprawie ustanowienia środków tymczasowych na rzecz Włoch i Grecji, przewidująca obowiązkowy system kwotowy obejmujący aż 120 tys. migrantów, napotkała jawny opór niektórych państw Europy Środkowo-Wschodniej. Rządy Republiki Czeskiej, Słowacji, Węgier i Rumunii uznały ją za „dyktat”. Premier Słowacji Robert Fico zapowiedział zaskarżenie decyzji do Trybunału Sprawiedliwości Unii Europejskiej, zaś premier Republiki Czeskiej Bohuslav Sobotka nie tylko sprzeciwił się kwotowemu systemowi relokacji migrantów, lecz także wskazał na pilną konieczność zakończenia konfliktów w Syrii i Libii jako sposobu na zażegnanie kryzysu migracyjnego Unii Europejskiej ${ }^{79}$.

76 Rada Unii Europejskiej, Protokół z posiedzenia Rady Unii Europejskiej (ds. Wymiaru Sprawiedliwości i Spraw Wewnętrznych) w dniu 22 września 2015 r., Bruksela, 13 X 2015, 12295/15, s. 3.

77 Rada Unii Europejskiej, Protokół z posiedzenia Rady Unii Europejskiej (ds. Wymiaru Sprawiedliwości i Spraw Wewnętrznych) w dniu 20 lipca 2015 r., Załącznik. Oświadczenie Niemiec i Francji, Bruksela, 22 IX 2015, 11088/15, s. 8-9.

78 Deutscher Bundestag, Verhandlungen des Deutschen Bundestages, Stenographische Berichte, 18. Wahlperiode, 120. Sitzung am 9. September 2015, s. 11606, (Gregor Gysi, Zieloni), 11613 (Merkel), 11619 (Thomas Oppermann, SPD), 11629 (Gerda Hasselfeldt, CDU/CSU), 11643 (Frank-Walter Steinmeier, SPD), [online] http://dip21.bundestag.de, 9 X 2017.

79 Ostatecznie w grudniu 2015 r. rządy Słowacji i Węgier zaskarżyły decyzję Rady do Trybunału Sprawiedliwości Unii Europejskiej, por. Stowacja i Wegry nie chca siępoddać „dyktatowi UE”, 2 XII 2012, s. 1-2, [online] http://www.dw.com, 9 X 2017; Stan wdrożenia decyzji relokacyjnej jest żatosny $w$ kazdym kraju UE, PAP, 12 I 2017, s. 1-2. Por. też: A. Potyrała, Pozamilitarne aspekty bezpieczeństwa międzynarodowego..., s. 304-306; T. Morozowski, Dziatania Komisji Europejskiej wobec kryzysu migracyjnego, „Biuletyn Instytutu Zachodniego” 2016, s. 3-4; A. Potyrała, S. Wojciechowski, „Za” i „przeciw”. Unijny dwugtos w sprawie systemu relokacji, „Biuletyn Instytutu Zachodniego. Seria specjalna - Uchodźcy w Europie" 2015, nr 197, s. 5. 
Rządy czterech wspomnianych państw złożyły nawet specjalne oświadczenia do protokołu z posiedzenia Rady Unii Europejskiej w dniu 22 września 2015 r. Rząd czeski uznał tę decyzję za pochopną. Jego zdaniem proponowany system relokacji nigdy nie będzie dziatat, jak należy, ponieważ wola relokowanych osób nie będzie w wystarczający sposób uwzględniana, nie wspominajac już nawet o aspekcie zwiąanym $z$ wtórnymi przeptywami tych osób $w$ strefie Schengen. W efekcie system ten zaowocuje przyciagnięciem do UE jeszcze większej liczby migrantów. Rząd czeski zakwestionował także samą procedurę przyjęcia decyzji przez Radę Unii Europejskiej. W jego opinii tak ważne decyzje polityczne, jak ustanowienie środków tymczasowych w dziedzinie ochrony międzynarodowej, należałoby przyjmować $\mathrm{w}$ drodze konsensu, niezależnie od możliwości przewidzianych $w$ Traktacie of funkcjonowaniu Unii Europejskiej. Uchwalenie takiej decyzji w trybie większości kwalifikowanej oznaczało, że UE odchodzi od koncepcji dobrowolnego udziatu państw cztonkowskich w proponowanym systemie relokacji, a to doprowadzi jedynie do ostabienia ducha wspótpracy w obrębie Unii Europejskiej - nawet jeśli taki krok jest podejmowany w imię solidarności. Dlatego zdaniem rządu czeskiego Unia nie powinna wprowadzać do wspólnego europejskiego systemu azylowego [...] nowego elementu sktadowego, jakim jest system relokacji ${ }^{80}$. Również rządy Rumunii, Słowacji i Węgier uznały system relokacji za niewłaściwy i nierozwiązujący kryzysu migracyjnego. Podejście takie było bowiem nakierowane jedynie na radzenie sobie z bezpośrednimi objawami kryzysu (Rumunia) ${ }^{81}$. System relokacji nie rozwiązywał podstawowych kwestii, takich jak nieuregulowane przeptywy wtórne, nie uzwględniał preferencji wyrażanych przez migrantów, a także działał jako czynnik nasilajacy naptyw obywateli krajów trzecich do panstw cztonkowskich (Słowacja) ${ }^{82}$. System taki winien raczej uzupełniać, a nie zastępować kompleksowe i efektywne wspólne dziatania w celu skutecznej kontroli na granicach zewnętrznych Unii Europejskiej (Węgry) ${ }^{83}$. Finlandia wstrzymała się od głosu, ponieważ - podobnie jak Czechy - zakwestionowała procedurę przyjęcia przez Radę Unii Europejskiej analizowanej decyzji. Niezwykle ważne było bowiem dla jej rządu, aby kwoty uchodźcze mogły być ustalane w rezolucji, a nie w akcie prawnym ${ }^{84}$.

80 Rada Unii Europejskiej, Protokół z posiedzenia Rady Unii Europejskiej (ds. Wymiaru Sprawiedliwości i Spraw Wewnętrznych) w dniu 22 września 2015 r., Załącznik. Oświadczenie Republiki Czeskiej, Bruksela, 13 X 2015, 12295/15, s. 4-5.

81 Rada Unii Europejskiej, Protokół z posiedzenia Rady Unii Europejskiej (ds. Wymiaru Sprawiedliwości i Spraw Wewnętrznych) w dniu 22 września 2015 r., Załącznik. Oświadczenie Rumunii, s. 7.

82 Rada Unii Europejskiej, Protokół z posiedzenia Rady Unii Europejskiej (ds. Wymiaru Sprawiedliwości i Spraw Wewnętrznych) w dniu 22 września 2015 r., Załącznik. Oświadczenie Słowacji, s. 7-8.

83 Rada Unii Europejskiej, Protokół z posiedzenia Rady Unii Europejskiej (ds. Wymiaru Sprawiedliwości i Spraw Wewnętrznych) w dniu 22 września 2015 r., Załącznik. Oświadczenie Węgier, s. 6.

${ }^{84}$ Rada Unii Europejskiej, Protokół z posiedzenia Rady Unii Europejskiej (ds. Wymiaru Sprawiedliwości i Spraw Wewnętrznych) w dniu 22 września 2015 r., Załącznik. Oświadczenie Finlandii, s. 6. Kilka tygodni później do grona państw kontestujących system relokacji przystąpiła Polska. 9 listopada 2015 r. w oświadczeniu załączonym do protokołu z posiedzenia Rady Unii Europejskiej rząd polski potwierdził swoje negatywne stanowisko w sprawie tzw. statego mechanizmu relokacji, por. Rada Unii Europejskiej, Protokół z posiedzenia Rady Unii Europejskiej (ds. Wymiaru Sprawiedliwości i Spraw Wewnętrznych) w dniu 9 listopada 2015 r., Załącznik. Oświadczenie Polski, Bruksela, 9 XII 2015, 13896/15, s. 5. 
Zalecenia komitetu koalicyjnego z 6 września 2015 r. ukształtowały stanowisko RFN wobec kryzysu migracyjnego Unii Europejskiej, ale jak się wkrótce okazało jedynie na krótką metę. Wobec trwającego nadal masowego napływu migrantów nakazem chwili stały się dalsze uzgodnienia na szczeblu unijnym, czego efektem były decyzje szefów państw i rządów z 23 września 2015 r., a następnie konkluzje Rady Europejskiej z 15 października tegoż roku, wyznaczające nowe priorytety Unii Europejskiej w walce z kryzysem, w tym m.in. porozumienie z Turcją oraz uszczelnienie granic zewnętrznych Unii. Rząd federalny zareagował ambiwalentnie. Kanclerz Merkel popierała te priorytety ${ }^{85}$, ale nie zgadzała się na całkowite zamknięcie wschodniego szlaku śródziemnomorskiego, co doprowadziło w marcu 2016 r. do otwartej konfrontacji z przewodniczącym Rady Europejskiej Tuskiem w tej sprawie. Z drugiej strony rząd federalny aktywnie zabiegał o przyspieszenie prac legislacyjnych nad wnioskiem ustawodawczym Komisji Europejskiej z 9 września 2015 r. w sprawie ustanowienia stałego kryzysowego mechanizmu relokacji migrantów ${ }^{86}$.

Wspomniana wyżej uchwała przewodniczących CDU, CSU i SPD z 5 listopada 2015 r. określiła stanowisko rządu federalnego przed posiedzeniem Rady Unii Europejskiej, które odbyło się cztery dni później i podczas którego przyjęto rezolucję polityczną w sprawie kryzysu migracyjnego Unii. W celu zmniejszenia dotychczasowej presji migracyjnej Rada Unii Europejskiej postanowiła: po pierwsze zintensyfikować prace nad utworzeniem Hotspotów w Grecji i we Włoszech, tak aby z końcem listopada tegoż roku osiągnęły one zdolność operacyjną; po drugie przyspieszyć procedury relokacji migrantów z tych dwóch państw m.in. poprzez wysłanie tam przez kraje uczestniczące do połowy listopada tegoż roku oficerów łącznikowych ds. relokacji; po trzecie w razie braku współpracy ze strony migrantów wykorzystywać w większym stopniu niż dotąd przewidziane w prawie Unii Europejskiej procedury azylowe na granicach lub w strefach tranzytowych, procedury przyspieszone, przepisy o niedopuszczalności składania kolejnych wniosków o azyl, a także środki przymusu, w tym zatrzymanie na okres realizacji procedur; po czwarte wspomóc potrzebujące tego państwa członkowskie w zakresie zarządzania granicami zewnętrznymi; po piąte kontynuować prace legislacyjne nad wnioskami Komisji Europejskiej z 9 września 2015 r. o ustanowieniu stałego

85 Za intensyfikacją rozmów z Turcją Merkel opowiedziała się po raz pierwszy 9 września 2015 r. w czasie debaty parlamentarnej w Bundestagu, poświęconej kryzysowi migracyjnemu, por. Deutscher Bundestag, Verhandlungen des Deutschen Bundestages, Stenographische Berichte, 18. Wahlperiode, 120. Sitzung am 9. September 2015, s. 11613, [online] http://dip21.bundestag.de, 9 X 2017. Jednocześnie Merkel jednoznacznie popierała zmiany w funkcjonowaniu Frontexu i ustanowienie zintegrowanego systemu zarządzania granicami zewnętrznymi Unii, por. tamże, s. 12558. Deutscher Bundestag, Verhandlungen des Deutschen Bundestages, Stenographische Berichte, 18. Wahlperiode, 145. Sitzung am 16. Dezember 2015, s. 14282-14283.

86 Deutscher Bundestag, Verhandlungen des Deutschen Bundestages, Stenographische Berichte, 18. Wahlperiode, 130. Sitzung am 15. Oktober 2015, s. 12558 (Merkel), 12561 (Oppermann); Deutscher Bundestag, Verhandlungen des Deutschen Bundestages, Stenographische Berichte, 18. Wahlperiode, 139. Sitzung am 25. November 2015, s. 13612 (Merkel), [online] http://dip21.bundestag. de, 9 X 2017; Deutscher Bundestag, Verhandlungen des Deutschen Bundestages, Stenographische Berichte, 18. Wahlperiode, 145. Sitzung am 16. Dezember 2015, s. 14283 (Merkel), [online] http:// dip21.bundestag.de, 9 X 2017. 
kryzysowego mechanizmu relokacji oraz w sprawie wspólnego wykazu bezpiecznych krajów pochodzenia; po szóste wspierać szybszą realizację harmonogramu liberalizacji reżimu wizowego z Turcją ${ }^{87}$.

Lansując od początku września 2015 r. politykę „otwartych drzwi” (Türöffnungspolitik), nazywaną też polityką "powitania” (Willkommenspolitik), rząd federalny dawał do zrozumienia, że jest gotów do wzięcia na siebie odpowiedzialności za zarządzanie kryzysem migracyjnym w całej Unii Europejskiej. Jednak w istocie było to jedynie działanie w afekcie. Aktywność rządu federalnego, zwłaszcza od września 2015 r., charakteryzowała się oportunizmem, brakiem zdecydowania i ograniczała zasadniczo do zwykłego reagowania na bieżące wydarzenia. W efekcie relacje Niemiec z państwami Europy Środkowo-Wschodniej uległy pogorszeniu, co skutkowało także pogłębieniem podziałów w samej Unii Europejskiej, a nawet tymczasową izolacją Niemiec w Unii. Długofalowymi konsekwencjami decyzji Merkel w Niemczech były: głęboki podział społeczeństwa niemieckiego na zwolenników i przeciwników przyjmowania migrantów, zmiany w jego strukturze socjalnej i etnicznej, a także wzmocnienie powstałej w 2013 r. populistycznej partii politycznej Alternatywy dla Niemiec (Alternative für Deutschland - AfD).

Samotna droge Niemiec (Alleingang Deutschlands) w Unii Europejskiej krytycznie oceniały w następnych miesiącach tamtejsze środowiska dziennikarskie, prawnicze i polityczne. „Rheinische Post” pisał wręcz o Europie samotników, zaś „Der Tagesspiegel” i „Frankfurter Rundschau” przestrzegały przed osamotnieniem rządu federalnego $\mathrm{w}$ walce $\mathrm{z}$ kryzysem migracyjnym i prawdopodobnym brakiem zrozumienia ze strony pozostałych państw członkowskich dla kolejnych niemieckich inicjatyw w tym zakresie $^{88} .13$ stycznia 2016 r. były prezes Trybunału Konstytucyjnego w Nadrenii Północnej-Westfalii Michael Bertrams zarzucił kanclerz Merkel przekroczenie uprawnień w polityce imigracyjnej oraz możliwe naruszenie konstytucji. Jego zdaniem polityka ta umożliwiła przedostanie się do Niemiec setek tysięcy uchodźców, co byto humanitarne (mitfühlend), ale nastąito bez jasnego planu i przede wszystkim bez zgody Bundestagu. Dlatego decyzję Merkel należałoby traktować jako przejaw autokratycznej demokracji kanclerskiej (selbstherrliche Kanzler-Demokratie) ${ }^{89}$.

18 lutego 2016 r. Prezydium FDP przyjęło uchwałę, w której obarczyło rząd federalny pełną odpowiedzialnością za dotychczasowe niepowodzenia w przezwyciężeniu

87 Rada Unii Europejskiej, Konkluzje Rady w sprawie środków na rzecz radzenia sobie z kryzysem uchodźczym i migracyjnym, Bruksela, 9 XI 2015, 13880/15, s. 2-5. Polska, Węgry i Słowacja w oświadczeniach załączonych do protokołu z posiedzenia Rady Unii Europejskiej odrzuciły postulat ustanowienia stałego kryzysowego mechanizmu relokacji, por. Rada Unii Europejskiej, Protokół z posiedzenia Rady Unii Europejskiej (ds. Wymiaru Sprawiedliwości i Spraw Wewnętrznych) w dniu 9 listopada 2015 r., Załącznik. Oświadczenie Węgier. Oświadczenie Polski. Oświadczenie Słowacji, Bruksela, 9 XII 2015, 13896/15, s. 4-5.

88 Ch. Ziedler, Europa der Einzelgänger, 21 IX 2015, s. 1-2, [online] http://www.rp-online.de, 9 X 2017; Nach dem Alleingang kann Angela Merkel nicht auf Hilfe hoffen, 13 X 2015, s. 1-2, [online] http://www.tagesspiegel.de, 9 X 2017; Deutschlands schlechter Alleingang, 19 X 2015, s. 1-2, [online] http://www.fr.de, 9 X 2017.

89 Merkels Alleingang war ein Akt der Selbstermächtigung, 13 I 2016, s. 1-2, [online] https://www.welt.de, $9 \times 2017$. 
kryzysu migracyjnego w Unii Europejskiej. Z powodu nieskoordynowanych działań rządu federalnego oraz błędnych sygnałów wysyłanych osobiście przez kanclerz Merkel $w$ wielu cześsiach świata powstato [bowiem] wrażenie, jakoby niemieckie prawo azylowe generalnie nie przewidywato dla migrantów żadnych przestanek i ograniczeń. Taka postawa zachęciła tylko tysiące migrantów do przyjazdu do Niemiec, ale jej konsekwencje sq katastrofalne. Kultura powitania (Willkommenskultur) wywołała ostatecznie poczucie strachu, odrzucenia, a cześsciowo nawet histerii w niemieckim społeczeństwie. Dlatego nakazem chwili stało się podjęcie przez rząd federalny działań mających na celu wyjście Niemiec z izolacji politycznej w Europie. Można by to osiągnąć przez poszukiwanie wraz $\mathrm{z}$ „partnerami europejskimi” wspólnych dla całej Unii Europejskiej kompromisowych rozwiązań $w$ zakresie prawa azylowego ${ }^{90}$.

W marcu 2016 r. rząd federalny zmienił swoją dotychczasową retorykę na temat sposobów i instrumentów przezwyciężenia kryzysu migracyjnego. Uwidoczniło się to najmocniej w deklaracji rządowej przedstawionej 16 marca 2016 r. w Bundestagu przez kanclerz Merkel. O ile dotąd priorytetowe znaczenie dla rządu federalnego miała solidarność wszystkich państw członkowskich w sprawie kwotowego podziału migrantów, o tyle odtąd Merkel kładła duży nacisk także na inne instrumenty o ogólnoeuropejskim charakterze (gesamteuropäische Lösung). W interesie całej Unii Europejskiej leżał już nie tylko sprawiedliwy i solidarny podział uchodźców, w tym planowana przez Komisję Europejską rewizja rozporządzenia Dublin III, lecz także ponowne zniesienie kontroli granicznych wprowadzonych w dziewięciu państwach członkowskich strefy Schengen, w tym w Niemczech, współpraca z Turcją jako największym krajem tranzytowym dla migrantów, a także kooperacja z państwami ich pochodzenia w Afryce i Azji w celu zlikwidowania przyczyn migracji ${ }^{11}$.

Masowy napływ migrantów do Unii Europejskiej wschodnim szlakiem śródziemnomorskim udało się przezwyciężyć dopiero po podpisaniu 18 marca 2016 r. umowy z Turcją. Rokowania pomiędzy Unią Europejską a Turcją w sprawie ograniczenia lub powstrzymania napływu uchodźców trwały od jesieni 2015 r. Rząd federalny aktywnie wspierał te negocjacje, potwierdzając to podczas debat parlamentarnych w Bundestagu 15 października i 25 listopada 2015 r., wizyty Merkel 18 października 2015 r. w Turcji czy też wspólnej wizyty Tuska, Merkel i Timmermansa 23 kwietnia 2016 r. w tymże $\mathrm{kraju}^{92}$. W czasie obu debat parlamentarnych Merkel mówiła po raz pierwszy o kluczo-

90 Beschluss des Präsidiums der FDP, Berlin, 18 II 2016, Für eine verantwortungsvolle und geordnete Flüchtlingspolitik: Fünf Punkte, die Bundeskanzlerin jetzt in Euriopa durchsetzen muss, s. 1-2, [online] http://www.fdp.de, 9 X 2017.

91 Deutscher Bundestag, Verhandlungen des Deutschen Bundestages, Stenographische Berichte, 18. Wahlperiode, 160. Sitzung am 16. März 2016, s. 15745-15749, [online] http://dip21.bundestag. de, 9 X 2017. Por. też Dieser Länder kontrollieren ibre Grenzen, 26 IX 2016, s. 1, [online] http://www. oe24.at, 9 X 2017.

92 R. Romaniec, Merkel $w$ Turcji, czyli coś za coś, 18 X 2015, s. 1-2, [online] http://www.dw.com/pl, 9 X 2017; Merkel oferuje Turcji brak wiz i szybką akcesję w zamian za przyjęcie imigrantów, 19 X 2015, s. 1-2, [online] https://www.wprost.pl, 9 X 2017; Tusk, Merkel i Timmermans jada do Turcji rozmawiać o imigrantach, PAP, 15 IV 2016, s. 1; Tusk chwali Turcje i zapewnia: pierwsze pieniadze za 2 lub 3 miesiace, 25 IV 2016, s. 1, [online] http://www.tvn24.pl, 9 X 2017; Donald Tusk, Angela Merkel i Frans Timmermans odwiedzili obóz dla uchodźców, 23 IV 2015, s. 1, [online] http://fakty.interia.pl, 9 X 2017. 
wej roli Turcji dla rozwiązania kryzysu oraz wyrażała poparcie rządu federalnego dla toczących się w tej sprawie negocjacji Unii z Turcją. 18 października doszło do pierwszych niemiecko-tureckich rozmów sondażowych na ten temat. Pod koniec listopada rząd federalny aktywnie włączył się do prac nad przyjęciem agendy posiedzenia szefów państw i rządów Unii z premierem Turcji Ahmetem Davutoğlu 29 listopada 2015 r. w Brukseli. Natomiast 16 grudnia 2015 r. kanclerz wyrażała zadowolenie z dotychczasowych ustaleń pomiędzy Unią Europejską a Turcją, a także nadzieję, że pozwolą one w dużej mierze na przezwyciężenie kryzysu ${ }^{93}$.

Podczas spotkania szefów państw i rządów Unii z premierem Davutoğlu przyjęto wspólny plan działania o zacieśnieniu współpracy między obu stronami w zakresie zwalczania nielegalnej migracji ${ }^{94}$. Jednak przełomowe znaczenie miało posiedzenie szefów państw i rządów Unii Europejskiej z udziałem premiera Davutoğlu, do którego doszło 7 marca 2016 r. w Brukseli. Zawarto bowiem wówczas wstępne porozumienie w sprawie zasad współpracy z Turcją oraz instrumentów jej realizacji ${ }^{95}$. W przeddzień tego posiedzenia odbyło się wszakże spotkanie Merkel z Davutoğlu oraz holenderskim premierem Markiem Rutte, jako szefem rządu sprawującego prezydencję w Unii Europejskiej. I to właśnie podczas tego spotkania ustalono zarys porozumienia z 7 marca, doprecyzowanego następnie 18 marca 2016 r. w umowie zawartej z rządem Turcji. Różnice zdań pomiędzy przewodniczącym Rady Europejskiej Tuskiem a kanclerz Merkel na temat sposobów rozwiązania kryzysu migracyjnego spowodowały, że Tusk nie tylko nie został na to spotkanie zaproszony, ale nawet nie został o nim poinformowany. Wola osiągnięcia przez Merkel wymiernego sukcesu w przezwyciężeniu kryzysu migracyjnego Unii Europejskiej przesłoniła nie tylko dawną osobistą sympatię wobec Tuska, lecz także wskazywała na ignorowanie przez nią instytucji Unii. Podczas gdy Tusk opowiadał się za bardziej rygorystyczną polityką wobec wysiedleńców i wzywał państwa bałkańskie do zamknięcia granic, znajdując oparcie w działaniach polityków z państw Europy Środkowo-Wschodniej, a nawet austriackiego ministra spraw zagranicznych Sebastiana Kurza (ÖVP) ${ }^{96}$, Merkel sprzeciwiała się zaryglowaniu wschodniego szlaku

93 Deutscher Bundestag, Verhandlungen des Deutschen Bundestages, Stenographische Berichte, 18. Wahlperiode, 130. Sitzung am 15. Oktober 2015, s. 12557, [online] http://dip21.bundestag.de, 9 X 2017; Deutscher Bundestag, Verhandlungen des Deutschen Bundestages, Stenographische Berichte, 18. Wahlperiode, 139. Sitzung am 25. November 2015, s. 13612, [online] http://dip21.bun destag.de, 9 X 2017; Deutscher Bundestag, Verhandlungen des Deutschen Bundestages, Stenographische Berichte, 18. Wahlperiode, 145. Sitzung am 16. Dezember 2015, s. 14283, [online] http://dip21. bundestag.de, 9 X 2017.

9415 października 2015 r. plan ten został uzgodniony ad referendum między Komisją Europejską a rządem tureckim i jeszcze w tym samym dniu przyjęty przez Radę Europejską, por. European Commission - Fact Sheet, EU-Turkey joint action plan, Brussels, 15 X 2015, MEMO 1558/60, s. 1-2; Posiedzenie Rady Europejskiej w dniu 15 października 2015 r., Konkluzje, Bruksela, 16 X 2015, EUCO 26/15, s. 1.

95 Rada Europejska, Szczyt szefów państw i rządów UE z Turcją, 7 marca 2016 r., Oświadczenie szefów państw i rządów UE, Bruksela, 8 III 2016, s. 1-2, [online] http://www.consilium.europa.eu, 9 X 2017. "Flüchtlingsdrama vor dem Gipfel” - Sebastian Kurz bei Anne Will, 6 III 2016, [online] https://www. youtube.com, 9 X 2017. 
śródziemnomorskiego. Gdy Tusk zabiegał o to, aby do oświadczenia szefów rządów i państw członkowskich Unii Europejskiej ze spotkania z Davutoğlu w dniu 7 marca 2016 r. włączyć passus stanowiący, że uzgodnienia z Turcją oznaczają zamknięcie tego szlaku dla wysiedleńców, Merkel sprzeciwiała się temu ${ }^{97}$. Ostatecznie w oświadczeniu znalazło się jednak kompromisowe sformułowanie, stanowiące, że nieuregulowane przepływy migracyjne wzdłuż wspomnianego szlaku dobiegty obecnie końca. Jednocześnie postanowiono, że to właśnie przewodniczący Rady Europejskiej będzie odpowiedzialny za przygotowanie ostatecznej umowy z Turcją z poszanowaniem prawa europejskiego i międzynarodowego ${ }^{98}$. Z drugiej strony aktywne zaangażowanie kanclerz Merkel w wynegocjowanie i podpisanie 18 marca 2016 r. umowy z Turcją pozwoliło rządowi federalnemu na ostateczne wyjście z tymczasowej izolacji politycznej w Unii Europejskiej, w której znajdował się on od września 2015 r.

Reakcje rządu federalnego i opozycji parlamentarnej na negocjacje i zawarcie umowy z Turcją różniły się diametralnie. Podczas gdy rząd federalny traktował tę umowę jako sukces Unii Europejskiej i Niemiec, partie opozycyjne oceniały ją krytycznie. Z perspektywy niemal sześciu miesięcy od jej wejścia w życie, podczas debaty parlamentarnej w Bundestagu 7 września 2016 r., kanclerz Merkel określała ją jako modelowe rozwiązanie dla podobnych porozumień, które należałoby zawrzeć w przyszłości m.in. z rządami Egiptu, Tunezji i Libii, ale pod warunkiem, że w tym ostatnim państwie dojdzie do ustabilizowania sytuacji wewnątrzpolitycznej. Natomiast minister spraw zagranicznych Steinmeier wskazywał na znaczenie geopolityczne Turcji dla uregulowania sytuacji międzynarodowej na Bliskim Wschodzie i w Afryce Północnej. W jego opinii państwo to winno odegrać „kluczową rolę” w przyszłym rozwiązaniu konfliktów w Syrii, Iraku i Libii ${ }^{99}$. Z kolei partie opozycyjne Sojusz 90/Zieloni oraz Lewica kontestowały umowę z Turcją. Dietmar Bartsch (Sojusz 90/Zieloni) argumentowat, że Unia Europejska stała się w ten sposób zakładnikiem prezydenta Erdoğana, który najpóźniej po nieudanym puczu z lipca 2016 r. doprowadził w Turcji do likwidacji demokracji, rządów prawa i praw człowieka, a wartości te nigdy nie powinny być przecież przedmiotem targów dyplomatycznych. Michael Leutert (Lewica) zarzucał Unii Europejskiej, że analizowana umowa została zawarta pod presją tureckiego rządu, który w zamian oczekiwał ustępstw Unii w sprawie liberalizacji reżimu wizowego, na co nie powinna się ona zgodzić z powodu niespełniania kryteriów wizowych przez Turcję ${ }^{100}$.

97 M. Stabenow, EU-Gipfel zur Flüchtlingskrise. Merkel und Tusk sehen Durchbruch, „Frankfurter Allgemeine Zeitung” 2015, 26 III, s. 1-2; „Wbit jej nóż w plecy...”. Starcie Tuska z Merkel w sprawie imigrantów. Kulisy szczytu w Brukseli, PAP, 13 III 2015, s. 1-2.

98 Rada Europejska, Szczyt szefów państw i rządów UE z Turcją, 7 marca 2016 r., Oświadczenie szefów państw i rządów UE, s. 1-2.

99 Deutscher Bundestag, Verhandlungen des Deutschen Bundestages, Stenographische Berichte, 18. Wahlperiode, 186. Sitzung am 7. September 2016, s. 18415 (Merkel), 18451 (Steinmeier), [online] http://dip21.bundestag.de, 9 X 2017.

100 Tamże, s. 18409-18410 (Bartsch), 18453 (Leutert). Już w czasie debaty w Bundestagu 28 kwietnia 2016 r. Göring-Eckardt (Sojusz 90/Zieloni) zarzucała Unii Europejskiej, że umowa z Turcją została zawarta za cenę wolności słowa i prasy, które nie są w tym państwie przestrzegane, zaś jedynym jej pozytywnym aspektem jest fakt, iż może ona stanowić zaczątek rozwiązania europejskiego dla kryzysu 
Bardzo rozbieżne były również poglądy koalicji rządowej i opozycji parlamentarnej w Niemczech na temat kontrowersyjnego wniosku ustawodawczego Komisji Europejskiej z 4 maja 2016 r. w sprawie zmiany rozporządzenia Dublin III, przewidującej ustanowienie korekcyjnego mechanizmu przydziału wniosków oraz bardzo wysokiego podatku solidarnościowego dla państw odmawiających zgody na przymusowe przyjmowanie azylantów. Wniosek został krytycznie przyjęty zarówno w państwach Europy Południowej, jak i w krajach Europy Środkowo-Wschodniej. Państwa najbardziej obciążone masowym napływem migrantów, Włochy i Grecja, kwestionowały przepisy umożliwiające odmowę udziału danego kraju w korekcyjnym mechanizmie przydziału wniosków nawet za rekompensatą. Natomiast państwa Grupy Wyszehradzkiej podważały zarówno ideę ustanowienia takiego mechanizmu, jak i zamysł wprowadzenia podatku solidarnościowego ${ }^{101}$.

Pod koniec września 2016 r. kraje Grupy Wyszehradzkiej zaproponowały rozwiązanie problemów wynikających ze słabości systemu dublińskiego za pomocą koncepcji elastycznej solidarności. Zakładała ona, że państwa członkowskie same - na podstawie swojego potencjału i doświadczenia - decydowałyby o tym, w jakiej formie będą uczestniczyć w polityce azylowej Unii Europejskiej i rozwiązywaniu kryzysu migracyjnego, zaś udział w programach dystrybucji uchodźców winien być dobrowolny. 17 listopada 2016 r., w przeddzień posiedzenia Rady Unii Europejskiej, prezydencja słowacka podczas nieformalnej kolacji ministrów spraw wewnętrznych przedstawiła szczegółowe propozycje, ujmując je tym razem w ramy koncepcji „efektywnej solidarności”. Koncepcja ta zakładała trzy scenariusze działań w zależności od natężenia napływu migrantów. Scenariusz pierwszy, dotyczący sytuacji przedkryzysowej, nakazywał państwom granicznym rejestrację migrantów, zaś wszystkim krajom członkowskim przeciwdziałanie wtórnym przepływom. Scenariusz drugi, przewidywany w sytuacji kryzysowej, nakładał na wszystkie państwa członkowskie obowiązek udzielenia zbiorowej pomocy krajom najbardziej dotkniętym skutkami kryzysu. Jednak o formie pomocy decydowałyby poszczególne państwa. Obok relokacji mogłyby to być: wkład finansowy, wsparcie dla agencji odpowiedzialnych za walkę z kryzysem czy też organizowanie deportacji nielegalnych migrantów. Scenariusz trzeci, dotyczący apogeum kryzysu, zakładał możliwość wprowadzenia tymczasowych relokacji na mocy art. 78 ust. 3 TFUE, ale pod warunkiem, że

migracyjnego Unii, choć z drugiej strony nie rozwiązuje sprawy masowego napływu uchodźców, lecz przyznaje jedynie 72 tys. obywateli Syrii możliwość legalnego przesiedlenia się do Unii, por. Deutscher Bundestag, Verhandlungen des Deutschen Bundestages, Stenographische Berichte, 18. Wahlperiode, 167. Sitzung am 28. April 2016, s. 16448, [online] http://dip21.bundestag.de, 9 X 2017.

101 Polska nie będzie ptacić za btędy Angeli Merkel, Rząd oburzony pomystem karania za nie przyjęcie uchodźców, 2 V 2016, s. 1, [online] http://www.pch24.pl, 9 X 2017; 250 tys. euro kary za kazdego nieprzyjętego migranta?, PAP, 4 V 2016, s. 1; Przymusowy rozdziat uchodźców i optaty. Komisja Europejska proponuje nowa politykę azylowa, 4 V 2016, s. 1, [online] http://www.newsweek.pl, 9 X 2017; A. Bartkiewicz, Milosz Zeman przeciwko relokacji imigrantów w UE, 26 XII 2016, s. 1, [online] http://www. rp.pl/Uchodzcy, 9 X 2017; Orban: Obywatel Wegier pracowatby 40 lat na kare za nieprzyjęcie uchodźcy, 14 VII 2016, s. 1, [online] http://alexjones.pl, 9 X 2017; M. Ostrowski, Ł. Wójcik, Czekając na odwilz, „Polityka” 2017, nr 14, s. 24; J. Szymańska, Perspektywy kompromisu w sprawie reformy wspólnego europejskiego systemu azylowego, „Biuletyn PISM” 2017, nr 12, s. 1. 
uczestnictwo w tym mechanizmie byłoby dobrowolne, a decyzję polityczną w sprawie jego uruchomienia podejmowałaby Rada Europejska. Koncepcja „efektywnej solidarności” została jednak skrytykowana przez Niemcy, Maltę, Grecję i Włochy ${ }^{102}$.

W okresie prezydencji maltańskiej wniosek ustawodawczy Komisji Europejskiej popierały Niemcy, Szwecja, Malta, Włochy i Grecja, zaś kraje Grupy Wyszehradzkiej nadal mu się sprzeciwiały. 8 marca 2017 r. szwedzka deputowana do Parlamentu Europejskiego Cecilia Wikström przedłożyła projekt zmiany wniosku ustawodawczego Komisji Europejskiej, proponując anulowanie przepisów o podatku solidarnościowym oraz obniżenie progu wartości referencyjnej ze 150\% do 100\% jako przesłanki uruchamiania procedury relokacyjnej. Konsekwencją odmowy udziału danego państwa w procedurze relokacji byłoby natomiast ograniczenie dla takiego kraju środków finansowych z funduszy strukturalnych oraz inwestycyjnych Unii ${ }^{103}$. W tej sytuacji Rada Europejska podczas posiedzenia w dniach 9-10 marca 2017 r. w Brukseli wezwała Komisję Europejską, Radę Unii Europejskiej i Parlament Europejski do osiągnięcia konsensu w sprawie polityki azylowej do końca czerwca tegoż roku ${ }^{104}$. Zabiegi przedstawicieli polskiego rządu o odroczenie tego terminu, podjęte jeszcze przed posiedzeniem Rady Europejskiej, zakończyły się niepowodzeniem z powodu sprzeciwu m.in. Niemiec, Francji i Szwecji ${ }^{105}$.

21 kwietnia 2017 r. prezydencja maltańska w dokumencie zatytułowanym Aspekt solidarności w procesie reformy systemu dublińskiego zaproponowała kompromisowe rozwiązanie dotychczasowego sporu w sprawie rewizji rozporządzenia Dublin III. Polegałoby ono na tym, że w okresie masowego napływu migrantów państwa objęte relokacją otrzymywałyby 60 tys. euro opłaty w ciągu pięciu lat za każdego migranta przyjętego w ramach przyznanej kwoty lub powyżej niej. Natomiast państwa, które przyjęłyby mniej migrantów niż liczba określona w systemie kwotowym, musiałyby uiścić taką samą opłatę za każdego nieprzyjętego migranta. $\mathrm{Z}$ drugiej strony jednak propozycje prezydencji maltańskiej przewidywały „alternatywne formy solidarności" dla państw, które nie chciałyby wypełniać swoich zobowiązań wynikających z systemu kwotowego. Alternatywą mogłoby być oddelegowanie dodatkowej liczby urzędników do ESGiP lub EASO. Korekcyjny mechanizm przydziału wniosków mógłby zostać wyłączony jedynie $w$ sytuacji ciężkiego kryzysu, tzn. wtedy gdy liczba migrantów przewidzianych do relokacji byłaby wyższa niż 200 tys. osób dla całej

102 J. Szymańska, Perspektywy kompromisu w sprawie reformy..., s. 1-2; A. Widzyk, UE nadal podzielona w sprawie reformy polityki migracyjnej, 20 XI 2016, s. 1-2; Nie ma zgody w UE w sprawie migrantów. Niemcy apelują o minimum solidarności, PAP, 18 XI 2016, s. 1-2.

103 Nowe przepisy UE uderza w Polskę. Nie dostaniemy funduszy, bo nie przyjmujemy uchodźców, PAP, 8 III 2017, s. 1-2.

104 Posiedzenie Rady Europejskiej w dniach 9-10 marca 2017 r. w Brukseli, Konkluzje przewodniczącego Rady Europejskiej, Bruksela, 9 III 2017 (OR.EN), s. 1. Rada Europejska omówiła przygotowane wcześniej konkluzje, ale nie zostały one formalnie zatwierdzone przez nią jako instytucję, lecz poparte przez 27 szefów państw i rządów, z wyjątkiem Polski. Przyczyną był spór w innej sprawie pomiędzy Polską a pozostałymi państwami członkowskimi, dotyczący wyboru Tuska na stanowisko przewodniczącego Rady Europejskiej.

105 Koniec szczytu UE z mocnym akcentem: ostra wymiana zdań między liderami, PAP, 10 III 2017. 
Unii Europejskiej w ciągu danego roku. W takiej sytuacji obowiązywałyby tylko minimalne standardy przewidziane w konwencji genewskiej w sprawie statusu uchodźców z 28 lipca 1951 r. ${ }^{106}$

\section{UWAGI KOŃCOWE}

W latach 2011-2014 stanowisko rządu federalnego wobec kryzysu migracyjnego Unii Europejskiej ewoluowało od stanowczej odmowy przyjęcia w $2011 \mathrm{r}$. afrykańskich migrantów uciekających przed skutkami wojny domowej w Libii (rząd CDU/CSU/FDP) do przekonania o konieczności opracowania Strategii migracji i rozwoju, a także o potrzebie wprowadzenia zmian w niemieckim prawie azylowym w 2013 r. (rząd CDU/ CSU/SPD). Od 2014 r. rząd federalny coraz mocniej apelował do rządów pozostałych państw członkowskich Unii o solidarny i sprawiedliwy podział odpowiedzialności za uchodźców. Partie koalicji rządowej wprowadziły także ten postulat do swoich dokumentów programowych: SPD uczyniła to w programie rządowym na lata 2013-2017, CDU w uchwale Zjazdu Federalnego z kwietnia 2014 r., zaś CSU w uchwale przyjętej przez Zjazd Krajowy w grudniu $2014 \mathrm{r}$.

W 2015 r. zarówno rząd koalicyjny CDU/CSU/SPD, jak i partie opozycji parlamentarnej zostały w pełni zaskoczone przez kryzys migracyjny w Unii Europejskiej. Żadna ze stron nie była przygotowana ani na tak masowy napływ migrantów w tak krótkim czasie, ani na bezradność Unii w obliczu kryzysu. Mimo to rząd federalny dawał do zrozumienia, że jest gotów do wzięcia na siebie odpowiedzialności za zarządzanie kryzysem w całej UE. Jednak faktycznie jego aktywność, zwłaszcza od września do listopada 2015 r., charakteryzowała się oportunizmem, brakiem zdecydowania i ograniczała zasadniczo do zwykłego reagowania na bieżące wydarzenia. Mimo iż kanclerz Merkel sama przyczyniła się do pogłębienia kryzysu migracyjnego w Unii Europejskiej, rząd federalny uzyskał realny wpływ na decyzje instytucji Unii Europejskiej dotyczące reformy polityki imigracyjnej i kontroli granic zewnętrznych oraz polityki azylowej. Wyrażało się to m.in. w przeforsowaniu decyzji Rady Unii Europejskiej z 22 września 2015 r. o ustanowieniu tymczasowego systemu relokacji migrantów na korzyść Włoch i Grecji, konsekwentnym wspieraniu projektu Komisji Europejskiej z 9 września 2015 r. przewidującego ustanowienie stałego kryzysowego mechanizmu relokacji, a także bardzo kontrowersyjnego projektu Komisji z 4 maja 2016 r. w sprawie ustanowienia automatycznego korekcyjnego mechanizmu przydziału wniosków (the fairness mechanism). Ponadto rząd federalny aktywnie współuczestniczył w wynegocjowaniu przełomowej dla dalszej dynamiki kryzysu migracyjnego umowy z Turcją z 18 marca 2016 r., której realizacja doprowadziła do radykalnego powstrzymania masowego napływu migrantów wschodnim szlakiem śródziemnomorskim do Unii Europejskiej.

106 P. Müller, EU-Streit um Flüchtlingsquoten. Wer viele aufnimmt, soll belohnt werden, 27 IV 2017, s. 1-2, [online] http://www.spiegel.de, 9 X 2017. Rząd federalny nalegał na to, aby każde państwo członkowskie wypełniło przynajmniej $50 \%$ przewidywanej kwoty. 


\section{BIBLIOGRAFIA}

\section{Źródła}

10 Punkte für eine bessere Flüchtlings- und Einwanderungspolitik. Beschluss des Präsidiums der FDP vom 26. August 2015 in Berlin, [online] http://www.fdp.de.

26. Bundesparteitag der CDU Deutschlands am 5. April 2014 in Berlin, „Gemeinsam Erfolgreich in Europa”, Europapolitischer Beschluss des 26. Parteitages der CDU Deutschlands, Berlin 2014.

28. Bundesparteitag der CDU am 14.-15. Dezember 2015 in Karlsruhe, Beschlüsse, Karlsruher Erklärung zu Terror und Sicherheit, Flucht und Integration, [online] http://www.cdu.de.

29. Bundesparteitag der CDU am 6.-7. Dezember 2016 in Essen, Beschlüsse, Orientierung in schwieriegen Zeiten - für ein erfolgreiches Deutschland und Europa, [online] http://www.cdu.de.

33. Ordentliche Bundesdelegiertenkonferenz am 25.-27. November 2011 in Kiel, Die Zukunft ist Europa, [online] https://www.gruene.de.

34. Ordentliche Bundesdelegiertenkonferenz am 16.-18. November 2012 in Hannover, Beschlüsse, Europa ensteht durch Taten, [online] https://www.gruene.de.

35. Ordentliche Bundesdelegiertenkonferenz vom Bündnis 90/Die Grünen vom 26.-28. April 2013 in Berlin, Zeit für den Grünenwandel, Teilhaben, Einmischen, Zukunft schaffen, Bundestagswahlprogramm 2013 von Bündnis 90/Die Grünen, Berlin 2013.

63. Ordentlicher Bundesparteitag der FDP am 22. April 2012 in Karlsruhe. Beschlüsse, Verantwortung für die Freiheit, Karlsruher Freiheitsthesen der FDP für eine offene Bürgergesellschaft, [online] http://www.fdp.de.

66. Ordentlicher Bundesparteitag der FDP am 16. Mai 2015 in Berlin, Beschlüsse, Für ein weltoffenes Deutschland - die Einwanderungs- und Flüchtlingspolitik der Freien Demokraten, [online] http://www.fdp.de.

Asylgesetz (AsylG) in der Fassung der Bekanntmachung vom 2. September 2008 (BGBl. I, S. 1798), das zuletzt durch Art. 2 Abs. 2 des Gesetzes vom 4. November 2016 (BGBl. I, S. 2460) geändert worden ist, Bundesgesetzblatt, 2008, Teil 1, Nr. 40, Bonn, 8 IX 2008.

Beschluss der Parteivorsitzenden von CDU, CSU und SPD, Berlin, 5 XI 2015.

Beschluss des Präsidiums der FDP, Berlin, 18 II 2016. Für eine verantwortungsvolle und geordnete Flüchtlingspolitik: Fünf Punkte, die Bundeskanzlerin jetzt in Euriopa durchsetzen muss, [online] http://www.fdp.de.

Bundesamt für Migration und Flüchtlinge, Aktuelle Zahlen zu Asyl, Berlin, IV 2017, [online] http://www.bamf.de.

Bundesamt für Migration und Flüchtlinge. Erst-, Folge-, Zweitanträge, 1 VIII 2016, [online] http://www.bamf.de.

Bundesamt für Migration und Flüchtlinge. Migrationsbericht 2015, 14 XII 2016, [online] http://www.bamf.de.

Bundesgesetzblatt, 2016, Teil 1, Nr. 12, Bonn, 16 III 2016.

Council of the European Union, Conclusions, Brussels, 14 IX 2015, 12002/1/15, REV 1.

Council of the European Union, Outcome of the Council Meeting (Justice and Home Affairs), Brussels, 14 IX 2015, 11969/15. 
Das Wir entscheidet, Das Regierungsprogramm 2013-2017, Berlin 2013.

Deutscher Bundestag, Verhandlungen des Deutschen Bundestages, Stenographische Berichte, 18. Wahlperiode, 112. Sitzung am 18. Juni 2015, [online] http://dip21.bundestag.de.

Deutscher Bundestag, Verhandlungen des Deutschen Bundestages, Stenographische Berichte, 18. Wahlperiode, 120. Sitzung am 9. September 2015, [online] http://dip21.bundestag.de. Deutscher Bundestag, Verhandlungen des Deutschen Bundestages, Stenographische Berichte, 18. Wahlperiode, 121. Sitzung am 10. September 2015, [online] http://dip21.bundestag.de. Deutscher Bundestag, Verhandlungen des Deutschen Bundestages, Stenographische Berichte, 18. Wahlperiode, 130. Sitzung am 15. Oktober 2015, [online] http://dip21.bundestag.de.

Deutscher Bundestag, Verhandlungen des Deutschen Bundestages, Stenographische Berichte, 18. Wahlperiode, 139. Sitzung am 25. November 2015, [online] http://dip21.bundestag.de. Deutscher Bundestag, Verhandlungen des Deutschen Bundestages, Stenographische Berichte, 18. Wahlperiode, 145. Sitzung am 16. Dezember 2015, [online] http://dip21.bundestag.de. Deutscher Bundestag, Verhandlungen des Deutschen Bundestages, Stenographische Berichte, 18. Wahlperiode, 160. Sitzung am 16. März 2016, [online] http://dip21.bundestag.de.

Deutscher Bundestag, Verhandlungen des Deutschen Bundestages. Stenographische Berichte, 18. Wahlperiode, 167. Sitzung am 28. April 2016, [online] http://dip21.bundestag.de.

Deutscher Bundestag, Verhandlungen des Deutschen Bundestages, Stenographische Berichte, 18. Wahlperiode, 186. Sitzung am 7. September 2016, [online] http://dip21.bundestag.de. Deutschlands Zukunft gestalten, Koalitionsvertrag zwischen CDU, CSU und SPD, 18. Legislaturperiode, Berlin, 14 XII 2013.

European Commission - Fact Sheet. EU-Turkey joint action plan, Brussels, 15 X 2015, MEMO $1558 / 60$.

Eurostat, Asylum and first time asylum applicants by citizenship, age and sex Annual aggregated data (rounded), [online] http://appssoeurostat.ec.europa.eu.

Forderungen an den Flüchtlingsgipfel. Beschluss des Bundesvorstands der FDP vom 17. Juni 2015 in Berlin, [online] http://www.fdp.de.

FRONTEX, Risk Analysis for 2016, Warszawa 2016.

Für ein zeitgemäßes Einwanderungskonzept, Beschluss des Bundesvorstands der FDP vom 19. Januar 2015 in Berlin, [online] http://www.fdp.de.

Gesetz zur Einführung beschleunigter Asylverfahren vom 11. März 2016, Bundesgesetzblatt, 2016, Teil 1, Nr. 12, Bonn, 16 III 2016.

Gesetz zur erleichterten Ausweisung von straffäligen Ausländern und zum erweiterten Ausschluss der Flüchtlingsanerkennung bei straffäligen Asylbewerbern vom 11. März 2016.

Integrationsgesetz vom 31. Juli 2016, Bundesgesetzblatt, 2016, Teil 1, Nr. 39, Bonn, 5 VIII 2016. Klarer Kurs bei der Zuwanderung. Humanität, Ordnung, Begrenzung, Beschluss des CSU-Parteivorstandes vom 9./10. September 2016 in Schwarzenfeld, [online] http://www.csu.de. Komisja Europejska, Kryzys związany z uchodźcami. Zdecydowane działania Komisji Europejskiej. Pytania i odpowiedzi, Strasburg, 9 IX 2015, [online] http://europa.eu/ rapid/ press-release_MEMO-15-5597.

Königsteiner Schlüssel, [online] http://www.gwk-bonn.de/themen/koenigsteiner-schluessel. Menschen in Not helfen, Zuwanderung ordnen und steuern, Integration sichern, Positionspapier von CDU und CSU vom 1. November 2015, Berlin, 1 XI 2015. 
Nordafrika, Flüchtlinge durch Libyenkrise, Bundeszentrale für Politische Bildung, 22 III 2011, [online] https://www.bpb.de.

Ordentlicher Bundesparteitag der SPD am 4.-6. Dezember 2011 in Berlin, Übersicht der angenommenen und überwiesenenen Anträge, [online] https://www.spd.de.

Parteitag der Christlich-Sozialen Union am 12.-13. Dezember 2014 in Nürnberg, Beschlüsse, Außenpolitik-Sicherheit-Europa, [online] http://www.csu.de.

Parteitag der Christlich-Sozialen Union am 20.-21. November 2015 in München. Beschlüsse, Deutschland braucht das starke Bayern, Migration-Leikultur-Integration, [online] http:// www.csu.de.

Parteitag der Christlich-Sozialen Union am 4.-5. November 2016 in München, Die Ordnung, Grundsatzprogramm der Christlich-Sozialen Union, [online] http://www.csu.de.

Posiedzenie Rady Europejskiej w dniach 9-10 marca 2017 r. w Brukseli, Konkluzje przewodniczącego Rady Europejskiej, Bruksela, 9 III 2017 (OR.EN).

Posiedzenie Rady Europejskiej w dniu 15 października 2015 r., Konkluzje, Bruksela, 16 X 2015 (EUCO 26/15).

Program der Partei Die Linke, Beschluss des Parteitages der Partei Die Linke vom 21. bis 23. Oktober 2011 in Erfurt, [online] https://www.die-linke.de.

Rada Europejska, Szczyt szefów państw i rządów UE z Turcją, 7 marca 2016, Oświadczenie szefów państw i rządów UE, Bruksela, 8 III 2016 r., [online] http://www.consilium.europa.eu.

Rada Unii Europejskiej, Konkluzje Rady w sprawie środków na rzecz radzenia sobie z kryzysem uchodźczym i migracyjnym, Bruksela, 9 XI 2015 r., 13880/15.

Rada Unii Europejskiej, Protokół z posiedzenia Rady Unii Europejskiej (ds. Wymiaru Sprawiedliwości i Spraw Wewnętrznych) w dniu 20 lipca 2015 r., Bruksela, 22 IX 2015, 11088/15.

Rada Unii Europejskiej, Protokół z posiedzenia Rady Unii Europejskiej (ds. Wymiaru Sprawiedliwości i Spraw Wewnętrznych) w dniu 20 lipca 2015 r., Załącznik. Oświadczenie Niemiec i Francji, Bruksela, 22 IX 2015, 11088/15.

Rada Unii Europejskiej, Protokół z posiedzenia Rady Unii Europejskiej (ds. Wymiaru Sprawiedliwości i Spraw Wewnętrznych) w dniu 22 września 2015 r., Bruksela, 13 X 2015, 12295/153.

Rada Unii Europejskiej, Protokół z posiedzenia Rady Unii Europejskiej (ds. Wymiaru Sprawiedliwości i Spraw Wewnętrznych) w dniu 22 września 2015 r., Załącznik. Oświadczenie Republiki Czeskiej, Bruksela, 13 X 2015, 12295/15.

Rada Unii Europejskiej, Protokół z posiedzenia Rady Unii Europejskiej (ds. Wymiaru Sprawiedliwości i Spraw Wewnętrznych) w dniu 22 września 2015 r., Załącznik. Oświadczenie Rumunii, Bruksela, 22 IX 2015, 11088/15.

Rada Unii Europejskiej, Protokół z posiedzenia Rady Unii Europejskiej (ds. Wymiaru Sprawiedliwości i Spraw Wewnętrznych) w dniu 22 września 2015 r., Załącznik. Oświadczenie Słowacji, Bruksela, 22 IX 2015, 11088/15.

Rada Unii Europejskiej, Protokół z posiedzenia Rady Unii Europejskiej (ds. Wymiaru Sprawiedliwości i Spraw Wewnętrznych) w dniu 22 września 2015 r., Załącznik. Oświadczenie Węgier, Bruksela, 22 IX 2015, 11088/15.

Rada Unii Europejskiej, Protokół z posiedzenia Rady Unii Europejskiej (ds. Wymiaru Sprawiedliwości i Spraw Wewnętrznych) w dniu 22 września 2015 r., Załącznik. Oświadczenie Finlandii, Bruksela, 22 IX 2015, 11088/15. 
Rada Unii Europejskiej, Protokół z posiedzenia Rady Unii Europejskiej (ds. Wymiaru Sprawiedliwości i Spraw Wewnętrznych) w dniu 9 listopada 2015 r., Załącznik. Oświadczenie Polski, Bruksela, 9 XII 2015, 13896/15.

Rada Unii Europejskiej. Protokół z posiedzenia Rady Unii Europejskiej (ds. Wymiaru Sprawiedliwości i Spraw Wewnętrznych) w dniu 9 listopada 2015 r., Załącznik. Oświadczenie Węgier. Oświadczenie Polski. Oświadczenie Słowacji, Bruksela, 9 XII 2015, 13896/15.

Sitzung des Koalitionsausschusses am 6. Septemebr 2015 r., [online] http://www.fluechtlingsrat-bw.de.

UNHCR, The UN Refugee Agency, Bureau for Europe, II 2017, [online] https://data2.unhcr. org/en/documents/details/563119.

Vorübergehende Wiedereinführung von Grenzkontrollen, De Maizière verkündet Wiedereinführung von Kontrollen an Binnengrenzen - Schwerpunkt vorerst Grenze zu Österreich, [online] http://www.bmi.bund.de.

\section{Monografie}

Handbook on European law relating to asylum, borders and immigration, Luxembourg 2014.

Węc J.J., Pierwsza polska prezydencja w Unii Europejskiej. Uwarunkowania - procesy decyzyjne osiagnięcia i niepowodzenia, Kraków 2012, Societas - Księgarnia Akademicka, 44.

Węc J.J., Spór o ksztatt ustrojowy Wspólnot Europejskich i Unii Europejskiej 1950-2010. Między idea ponadnarodowości a wspótpraca międzyrządowa. Analiza politologiczna, Kraków 2012, Societas - Ksiegarnia Akademicka, 41.

Węc J.J., Traktat Lizboński. Polityczne aspekty reformy ustrojowej Unii Europejskiej w latach 2007-2016, Kraków 2016, Societas - Księgarnia Akademicka, 36.

\section{Artykuły w czasopismach naukowych}

Dobrowolska-Polak J., Niemieckie przewodnictwo w Unii Europejskiej w procesie zarzadzania kryzysem migracyjnym, „Przegląd Zachodni” 2016, nr 3.

Koszel B., Unia Europejska, Niemcy i problem uchodźców (2014-2016), „Rocznik Integracji Europejskiej" 2016, nr 10.

Morozowski T., Dziatania Komisji Europejskiej wobec kryzysu migracyjnego, „Biuletyn Instytutu Zachodniego" 2016.

Potyrała A., Pozamilitarne aspekty bezpieczeństwa międzynarodowego - kryzys migracyjny 2015-2016, „Przegląd Strategiczny” 2016, nr 9.

Potyrała A., Wojciechowski S., „Za” $i$ "przeciw”. Unijny dwugtos $w$ sprawie systemu relokacji, „Biuletyn Instytutu Zachodniego. Seria specjalna - Uchodźcy w Europie” 2015, nr 197.

Szymańska J., Perspektywy kompromisu w sprawie reformy wspólnego europejskiego systemu azylowego, „Biuletyn PISM” 2017, nr 12.

Tendera-Waszczuk H., Kryzys migracyjny zagrożeniem dla realizacji projektu zjednoczonej Europy, „Krakowskie Studia Międzynarodowe” 2016, nr 3.

Trauner F., Wie sollen Flüchtlinge in Europa verteilt werden? Der Streit um einen Paradigmenwechsel in der EU-Asylpolitik, „Integration” 2016, Vol. 39, nr 2, [online] https://doi. org/10.5771/0720-5120-2016-2-93. 


\section{Artykuły prasowe i internetowe}

250 tys. euro kary za każdego nieprzyjętego migranta?, PAP, 4 V 2016.

Angela Merkel broni decyzji o otwarciu granicy dla uchodźców z Syrii, 12 IX 2015, [online] http://wiadomosci.onet.pl.

Angela Merkel czyli o zwycięstwie postpolityki, OAS, 21 X 2015.

Bartkiewicz A., Milosz Zeman przeciwko relokacji imigrantów w UE, 26 XII 2016, [online] http://www.rp.pl/Uchodzcy.

Banas G., Flüchtlingsfrage. Merkel: „Wir schaffen das”, „Frankfurter Allgemeine Zeitung” 2015, 31 VIII.

Bielecki J., Merkel strzelita sobie gola, 21 X 2015, [online] http://wiadomosci.wp.pl.

Btędy Merkel w polityce wobec uchodźców. Chwilowe otwarcie granic catkowicie odmienito Niemcy, PAP, 17 III 2017.

Czy Niemcy zmuszą Polskę do przyjęcia 100 tysięcy uchodźców?, 24 VIII 2015, [online] http:// www.defence24.pl.

De Maiziere erntet mit seinem Vorstoß zur Leitkultur Kritik, 1 V 2017, [online] http://www. sueddeutsche.de.

De Maiziere stellt zehn Thesen zur deutschen Leitkultur auf, 30 IV 2017, [online] http://www. sueddeutsche.de.

De Maiziere stößt mit Vorschlägen zur Leitkultur auf Kritik, 30 IV 2017, [online] http://www. bild.de.

Deutschlands schlechter Alleingang, 19 X 2015, [online] http://www.fr.de.

Dieser Länder kontrollieren ibre Grenzen, 26 IX 2016, [online] http://www.oe24.at.

Donald Tusk, Angela Merkel i Frans Timmermans odwiedzili obóz dla uchodźców, 23 IV 2015, [online] http://fakty.interia.pl.

Flüchtlingeprognose 2015. Bundesregierung rechnet mit bis zu 800.000 Asylbewerbern, 19 VIII 2015, [online] http://www.spiegel.de.

„Flüchtlingsdrama vor dem Gipfel” - Sebastian Kurz bei Anne Will, 6 III 2016, [online] https:// www.youtube.com.

Italien gegen den Rest Europas, 11 IV 2011, [online] http://www.zeit.de.

Junger österreichischer Außenminister spricht klar Text, 7 III 2016, [online] https://www.youtube.com.

Koniec szczytu UE $z$ mocnym akcentem: ostra wymiana zdań między liderami, PAP, 10 III 2017.

Leszek Miller: Merkel jest największym szkodnikiem Europy, 15 XI 2015, [online] https:// pl.sputniknews.com/polityka.

Merkel oferuje Turcji brak wiz iszybka akcesję w zamian za przyjecie imigrantów, 19 X 2015, [online] https://www.wprost.pl.

Merkels Alleingang war ein Akt der Selbstermächtigung, 13 I 2016, [online] https://www.welt.de.

Merkels drei große kleine Worte, 31 VIII 2015, [online] https://www.tagesschau.de.

Müller P., EU-Streit um Flüchtlingsquoten. Wer viele aufnimmt, soll belohnt werden, 27 IV 2017, [online] http://www.spiegel.de.

Nach dem Alleingang kann Angela Merkel nicht auf Hilfe hoffen, 13 X 2015, [online] http:// www.tagesspiegel.de. 
Nie ma zgody w UE wsprawie migrantów. Niemcy apelują o minimum solidarności, PAP, 18 XI 2016.

Niemieckie media: Merkel przyznaje się do btędu w sprawie uchodźców, [online] http://www. newsweek.pl.

Nowe przepisy UE uderza w Polskę. Nie dostaniemy funduszy, bo nie przyjmujemy uchodźców, PAP, 8 III 2017.

Orban: Obywatel Wegier pracowatby 40 lat na kare za nieprzyjęcie uchodźcy, 14 VII 2016, [online] http://alexjones.pl.

Ostrowski M., Wójcik Ł., Czekając na odwilż, „Polityka” 2017, nr 14.

PO i PiS jednym gtosem w sprawie imigrantów. Decyzje dopiero po wyborach, 1 IX 2015, [online] http://www.gazetaprawna.pl.

Polska nie będzie ptacić za btędy Angeli Merkel, Rząd oburzony pomystem karania za nieprzyjęcie uchodźców, 2 V 2016, [online] http://www.pch24.pl.

Przymusowy rozdziat uchodźców i optaty. Komisja Europejska proponuje nowa politykę azylowa, 4 V 2016, [online] http://www.newsweek.pl.

Romaniec R., Merkel w Turcji, czyli coś za coś, 18 X 2015, [online] http://www.dw.com/pl.

Stowacja i Wegry nie chca siępoddać "dyktatowi UE”, 2 XII 2012, [online] http://www.dw.com. Stabenow M., EU-Gipfel zur Flüchtlingskrise. Merkel und Tusk sehen Durchbruch, „Frankfurter Allgemeine Zeitung” 2015, 26 III.

Stan wdrożenia decyzji relokacyjnej jest żatosny w każdym kraju UE, PAP, 12 I 2017.

Tusk chwali Turcje i zapewnia: pierwsze pieniądze za 2 lub 3 miesiace, 25 IV 2016, [online] http://www.tvn24.pl.

Tusk, Merkel i Timmermans jadą do Turcji rozmawiać o imigrantach, PAP, 15 IV 2016.

W Niemczech narasta napięcie. CSU krytykuje Merkel za chęć przyjęcia uchodźców. „To btędny sygnat", PAP, 6 IX 2015.

„Wbit jej nóż w plecy...”. Starcie Tuska z Merkel w sprawie imigrantów. Kulisy szczytu w Brukseli, PAP, 13 III 2015.

Widzyk A., UE nadal podzielona w sprawie reformy polityki migracyjnej, PAP, 20 XI 2016. Ziedler Ch., Europa der Einzelgänger, 21 IX 2015, [online] http://www.rp-online.de.

Prof. dr hab. Janusz Józef WĘC - profesor zwyczajny nauk humanistycznych w zakresie historii powszechnej najnowszej i stosunków międzynarodowych. Kierownik Katedry Studiów nad Procesami Integracyjnymi w Instytucie Nauk Politycznych i Stosunków Międzynarodowych Uniwersytetu Jagiellońskiego w Krakowie. Autor ponad 200 publikacji naukowych wydanych w kraju i za granicą, w tym 19 monografii i syntez na temat ustroju Wspólnot Europejskich i Unii Europejskiej, integracji europejskiej i pozaeuropejskiej, stosunków polsko-niemieckich, najnowszej historii Niemiec, a także niemieckiego systemu politycznego. Ostatnio wydane monografie: Niemcy wobec reformy ustrojowej Unii Europejskiej w latach 2002-2016 (Kraków 2017); Traktat Lizboński. Polityczne aspekty reformy ustrojowej Unii Europejskiej w latach 2007-2015 (Kraków 2016); Pierwsza polska prezydencja w Unii Europejskiej. Uwarunkowania - procesy decyzyjne - osiagnięcia i niepowodzenia (Kraków 2012); Spór o ksztatt ustrojowy Wspólnot Europejskich i Unii Europejskiej w latach 1950-2010. Między idea ponadnarodowości a wspótpraca międzyrządowa. Analiza politologiczna (Kraków 2012). 